\section{ornl}
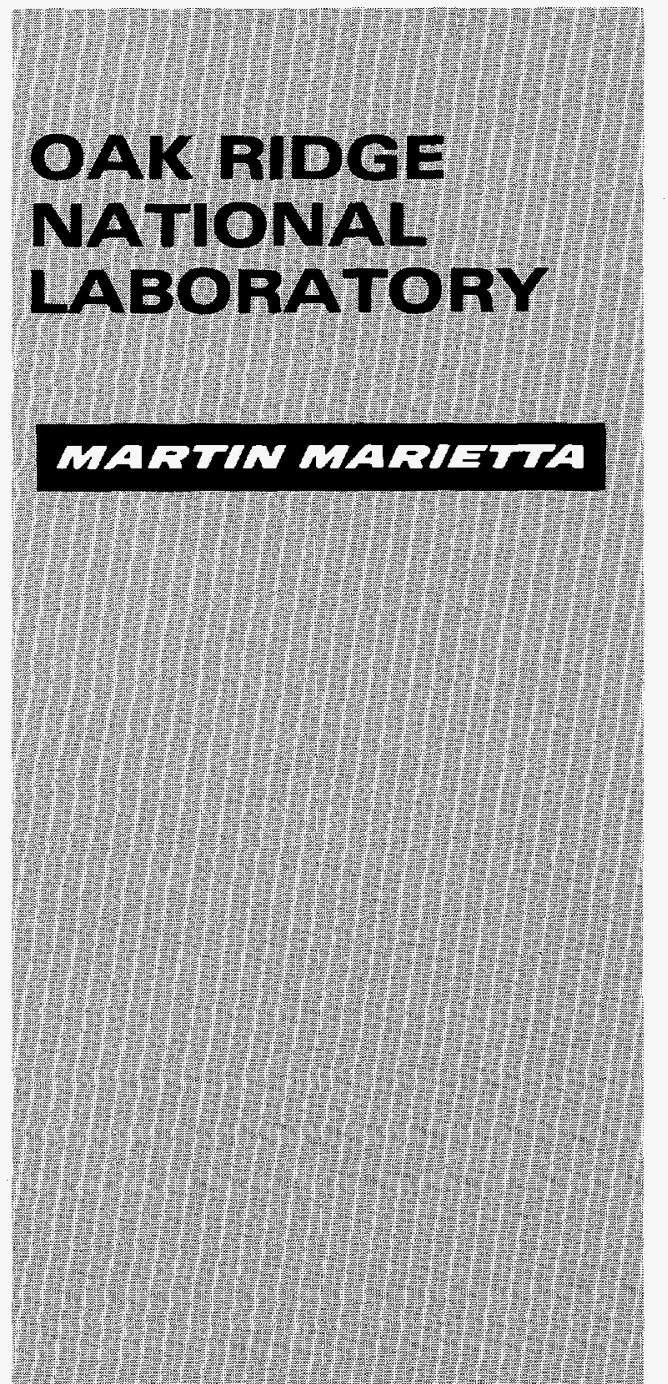

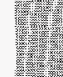
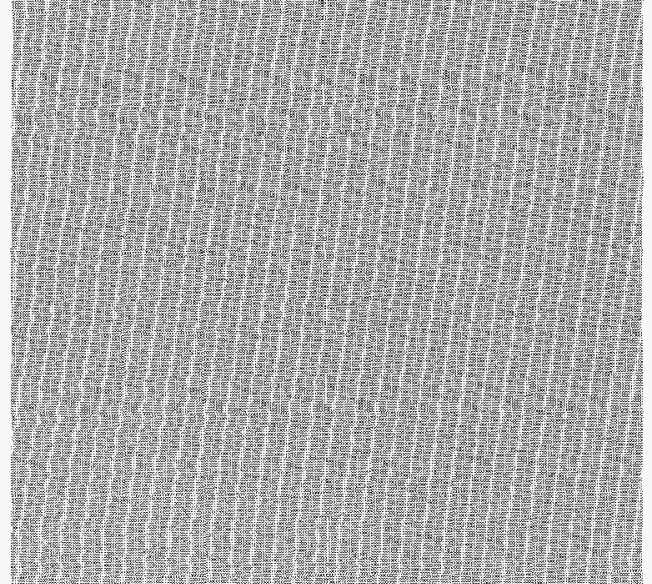

\section{MANAGED BY}

MARTIN MARIETHA ENERGY SYSTEMS, INC.

FOR THE UNITED STATES

DEPARTMENT OF ENERGY

ORNL/TM-12939

RE.

NON 211995

OSTI

\title{
Design Alternatives Report for the Cesium Removal Demonstration
}

\author{
J. F. Walker, Jr. \\ E. L. Youngblood
}


This report has been reproduced directly from the best available copy.

Available to DOE and DOE contractors from the Office of Scientific and Technical Information, P.O. Box 62, Oak Ridge, TN 37831; prices available from (615) 576-8401, FTS 626-8401.

Available to the public from the National Technical Information Service, U.S. Department of Commerce, 5285 Port Royal Rd., Springtield, VA 22161.

This report was prepared as an account of work sponsored by an agency of the United States Government. Neither the United States Government nor any agency thereof, nor any of their employees, makes any warranty, express or implied, or assumes any legal liability or responsibility for the accuracy, completeness, or usefulness of any information, apparatus, product, or process disclosed, or represents that its use would not infringe privately owned rights. Reference herein to any specific commercial product, process, or service by trade name, trademark, manufacturer, or otherwise, does not necessarily constitute or imply its endorsement, recommendation, or favoring by the United States Government or any agency thereof. The views and opinions of authors expressed herein do not necessarily state or reflect those of the United States Government or any agency thereot. 


\section{DISCLAMIER}

Portions of this document may be illegible in electronic image products. Images are produced from the best available original document. 
DESIGN ALTERNATIVES REPORT FOR THE

CESIUM REMOVAL DEMONSTRATION

J. F. Walker, Jr.

E. L. Youngblood

Date Published: September 1995

\section{Prepared by}

OAK RIDGE NATIONAL LABORATORY

Oak Ridge, Tennessee 37831-6285

managed by

LOCKHEED MARTIN ENERGY SYSTEMS

for the

U.S. DEPARTMENT OF ENERGY

under contract DE-AC05-84OR21400

\section{MASTER}

DISTRIBUTION OF THIS DOCUMENT IS UNLIMITEQ 


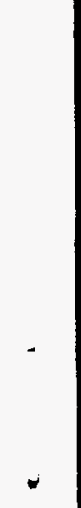


LIST OF TABLES $\ldots \ldots \ldots \ldots \ldots \ldots \ldots \ldots \ldots \ldots \ldots \ldots$

LIST OF FIGURES $\ldots \ldots \ldots \ldots \ldots \ldots \ldots \ldots \ldots \ldots \ldots \ldots \ldots \ldots$ vi

ABSTRACT $\ldots \ldots \ldots \ldots \ldots \ldots \ldots \ldots \ldots \ldots \ldots \ldots \ldots \ldots \ldots \ldots$ vii

1. INTRODUCTION $\ldots \ldots \ldots \ldots \ldots \ldots \ldots \ldots \ldots \ldots \ldots \ldots \ldots$

2. SORBENT ALTERNATIVES $\ldots \ldots \ldots \ldots \ldots \ldots \ldots \ldots \ldots \ldots \ldots \ldots \ldots \ldots$

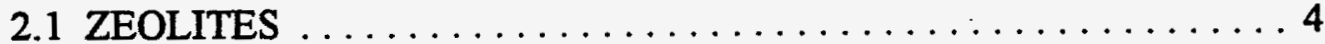

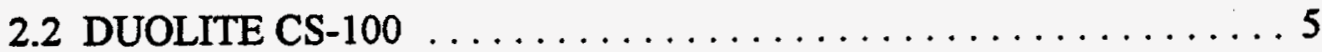

2.3 SAVANNAH RIVER RESIN $\ldots \ldots \ldots \ldots \ldots \ldots \ldots \ldots \ldots \ldots$

2.4 CRYSTALLINE SILICOTITANATE (CST) $\ldots \ldots \ldots \ldots \ldots 10$

2.5 POTASSIUM COBALT HEXACYANOFERRATE (KCOCF) . . . 12

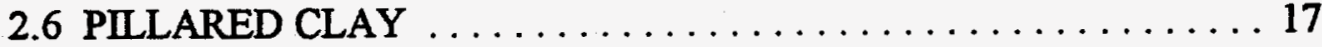

2.7 AMMONIUM MOLYBDOPHOSPHATE $\ldots \ldots \ldots \ldots \ldots \ldots \ldots$

2.8 EMBEDDED MEMBRANE TECHNOLOGY (EMT) $\ldots \ldots \ldots \ldots 18$

3. FACILITY ALTERNATIVES $\ldots \ldots \ldots \ldots \ldots \ldots \ldots \ldots \ldots \ldots$

3.1 BUILDING 7877 (LIQUID LOW-LEVEL WASTE

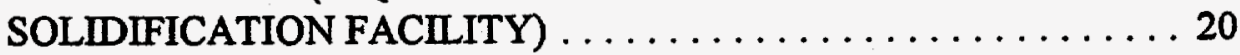

3.2 BUILDING 7860, THE NEW HYDROFRACTURE FACILITY) . . . 23

3.3 BUILDING 3517, FISSION PRODUCT DEVELOPMENT

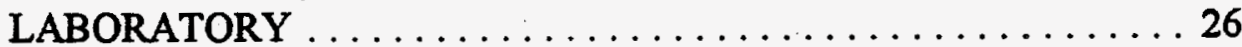

3.4 BUILDING 7930, THORIUM-URANIUM RECYCLE FACILITY $\ldots \ldots \ldots \ldots \ldots \ldots \ldots \ldots \ldots \ldots \ldots \ldots \ldots \ldots \ldots \ldots \ldots$

4. PROCESS ALTERNATIVES $\ldots \ldots \ldots \ldots \ldots \ldots \ldots \ldots \ldots \ldots \ldots \ldots \ldots$

4.1 THE MVST CHOSEN FOR TREATMENT IN CRC $\ldots \ldots \ldots \ldots 34$

4.2 MODE OF OPERATION $\ldots \ldots \ldots \ldots \ldots \ldots \ldots \ldots \ldots \ldots \ldots \ldots \ldots$

4.3 PROCESS FLOW RATES $\ldots \ldots \ldots \ldots \ldots \ldots \ldots \ldots \ldots \ldots \ldots \ldots \ldots$

4.4 REGENERATION ............................ 39

4.5 CRD UNIT SHIELDING REQUIREMENTS $\ldots \ldots \ldots \ldots \ldots \ldots 41$

5. CRD WASTE DISPOSAL ALTERNATIVES $\ldots \ldots \ldots \ldots \ldots \ldots \ldots 42$

5.1 PROCESSED SUPERNATE $\ldots \ldots \ldots \ldots \ldots \ldots \ldots \ldots \ldots$

5.2 LOADED ION-EXCHANGE RESINS $\ldots \ldots \ldots \ldots \ldots \ldots \ldots \ldots 44$

5.3 CONTAMINATED FILTERS $\ldots \ldots \ldots \ldots \ldots \ldots \ldots \ldots \ldots 47$

5.4 ACID ELUENT FROM REGENERATION OF LOADED

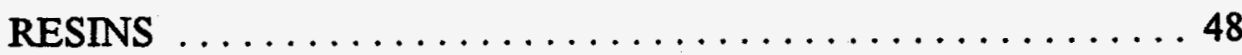


6.0 RELATIVE COST COMPARISON $\ldots \ldots \ldots \ldots \ldots \ldots \ldots \ldots$

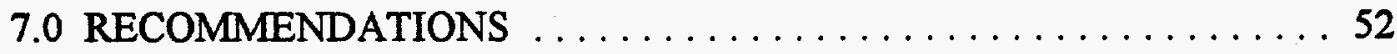

8.0 REFERENCES ........................ 54 


\section{LIST OF TABLES}

Table

1 Estimate of the relative costs of treating 25,000 gallons of supernate with potassium cobalt hexacyanoferrate (KCoCF), Savannah River resin (SRR), and crystalline silicotitanates (CST), based on the estimated resin costs only.

2 Summary of the advantages and disadvantages of Savannah River resin (SRR), crystalline silicotitanates (CST), and potassium cobalt hexacyanoferrate (KCoCF) for use in the cesium removal demonstration system

3 Summary of facility requirements necessary for operation of the cesium removal demonstration system 


\section{LIST OF FIGURES}

Figure

Page

1 Effects of potassium on cesium breakthrough curves for Savannah River Resin

2 The floor plan for the Liquid Low-Level Waste Solidification Facility (Building 7877)

3 The floor plan for the New Hydrofracture Facility (Building 7860) . . . . 25

4 The floor plan for the first and second floors of the Fission Product Development Laboratory (Building 3517)

5. The floor plan for the first floor and the transverse section for the Thorium-Uranium Recycle Facility (Building 7930)

6. A schematic diagram of the conceptual cesium removal demonstration system 



\begin{abstract}
The Cesium Removal Demonstration (CRD) project will use liquid low-level waste (LLLW) stored in the Oak Ridge National Laboratory Melton Valley Storage Tanks to demonstrate cesium removal from sodium nitrate-based supernates. This report presents the results of a conceptual design study to scope the alternatives for conducting the demonstration at ORNL. Factors considered included (1) sorbent alternatives, (2) facility alternatives, (3) process alternatives, (4) process disposal alternatives, and (5) relative cost comparisons. Recommendations included (1) that design of the CRD system move forward based on information obtained to date from tests with Savannah River Resin, (2) that the CRD system be designed so it could use crystalline silicotitanates (CST) if an engineered form of CST becomes available prior to the CRD, (3) that the system be designed without the capability for resin regeneration, (4) that the LLLW solidification facility be used for the demonstration, (5) that vitrification of the loaded resins from the CRD be demonstrated at the Savannah River Site, and (6) that permanent disposal of the loaded and/or vitrified resin at the Nevada Test Site be pursued.
\end{abstract}




\section{INTRODUCTION}

Department of Energy (DOE) underground storage tanks at Hanford, the Savannah River Site (SRS), Idaho National Engineering Laboratory (INEL), and Oak Ridge National Laboratory (ORNL) contain high concentrations of radioactive cesium. This cesium complicates efforts to treat and dispose of the waste by creating high gamma radiation fields which limit disposal of the waste to very expensive alternatives. Treatment methods are needed that remove the cesium from the bulk liquid, thus allowing the treated liquids to be processed into low-activity waste forms with less radiation exposure to individuals and at lower cost disposal options. The smaller volumes of concentrated cesium can then be handled remotely. The ORNL Waste Management and Remedial Actions Division (WMRAD) has identified a potential need for this capability prior to solidification and disposal of its liquid low-level waste (LLLW).

This project will use LLLW stored in the ORNL Melton Valley Storage Tanks (MVSTs) to demonstrate cesium removal from sodium nitrate-based supernates. The ORNL supernate is similar in chemical and radiological composition to liquid wastes stored at Hanford, and the SRS and may be useful as a surrogate for these facilities. Since the supernate at ORNL is easier to access, pilot plant demonstrations using the ORNL supernate will be less costly while still producing design and operating data that will be useful at all three sites. In particular, the 
Cesium Removal Demonstration (CRD) project will (1) demonstrate full-scale cesium removal technology using actual LLLW stored at the ORNL, (2) develop an approach for implementing cesium removal technology using modular, mobile equipment to be hăndled in existing facilities, (3) demonstrate decontamination capabilities for hands-on maintenance and possible transfer to other DOE sites, and (4) evaluate the ability to predict the performance of large-scale ion-exchange applications from small-scale column studies.

This report presents the results of a conceptual design study to scope the alternatives for conducting the demonstration at ORNL. Items discussed include (1) sorbent alternatives, (2) facility alternatives, (3) process alternatives, (4) waste disposal alternatives, and (5) relative cost comparisons. The results of this conceptual design study will be used as the basis for preparing specifications for an outside vendor to design and fabricate the CRD system.

\section{SORBENT ALTERNATIVES}

Several different sorbents are being considered for use in the CRD system. The material chosen will be based on data currently being generated from several projects funded through the Office of Technology Development. These include SR132002, Resorcinol Formaldehyde Resin Development; OR-132008-G, Comprehensive Sludge/Supernate Hot Cell Studies; and OR-132008-E, Hot 
Demonstration of Proposed Commercial Nuclide Removal Technology, as well as projects that are developing and testing new materials for cesium removal from salt solutions through the Efficient Separations Processing Integrated Program (ESPIP). Work being performed with the resorcinol formaldehyde resin leverages off previous work performed at the Savannah River Site where this resin was developed. In the Comprehensive Sludge/Supernate Hot Cell Studies (OR132008-G), surrogate wastes and actual MVST waste are used to produce equilibrium data on the various sorbents. As part of the Hot Demonstration of Proposed Commercial Nuclide Removal Technology Project (OR-13200-E), column tests are then performed with actual MVST supernate on the promising sorbents in order to provide data necessary for pilot plant design. Therefore, sorbents to be considered for use in the demonstration have to be available to be tested through project OR-132008-E prior to design of the CRD. The sorbents being considered for use in the CRD system include the following: (1) zeolites, (2) Duolite CS-100, (3) the resorcinol formaldehyde-based Savannah River Resin (SRR), (4) crystalline silicotitanate (CST), (5) potassium cobalt hexacyanoferrate (KCoCF), (6) pillared clays, (7) ammonium molybdophosphate (AMP), and (8) sorbents embedded in membranes. These sorbents are discussed below. 


\subsection{ZEOLITES}

Zeolites, inorganic aluminosilicate materials, have been used extensively for removal of radionuclides from wastewater. ${ }^{1}$ However, because of the high salt content (particularly sodium and potassium salts) of the MVST supernate, the amount of zeolite required to decontaminate the supernate would be large, probably $>2 \%$ of the waste volume treated. ${ }^{2}$ Regeneration of the zeolite is not practical. Because of the high salt content of the MVST supernate, zeolites are not considered to be primary candidates for use in the demonstration system for removing cesium from the MVST supernate. However, should the CRD use a resin that is capable of being regenerated, zeolites could be considered for use in the removal of cesium from eluent.

\subsection{DUOLTTE CS-100}

Duolite CS-100 is a phenol-formaldehyde ion-exchange resin that has been made commercially by Rohm and Haas, Inc., and is the current baseline technology for design activities for Hanford's high-level waste (HLW). Although the use of Duolite is considered to be a conservative choice because the resin is known to be stable in strong base and in strong radiation fields $\left(10^{9} \mathrm{rad}\right)$, work at ORNL's Process Waste Treatment Plant (PWTP) has demonstrated that the resin degrades during regeneration. Up to $\sim 200$ loading/regeneration cycles could be obtained 
before the resin had to be replaced. ${ }^{3}$ CS-100 is effective in removing cesium from sodium salts but less selective in removal from potassium salts. ${ }^{4} \mathrm{CS}-100$ can be eluted with nitric or formic acid. However, the SRS has recently developed a resorcinol formaldehyde resin that is somewhat similar to CS-100 but has superior cesium removal capabilities performance. ${ }^{5}$ The Savannah River Resin (SRR) has been found to be more selective than CS-100 in removing cesium from Hanfordsimulated waste. As a result, the use of the SRR could mean a reduction in the required size of the processing equipment as well as a reduction in the capital cost for construction of a full-scale system. ${ }^{5,6}$ The CS-100 resin is not considered to be a primary candidate for use in the CRD due to the superior performance of SRR.

\subsection{SAVANNAH RIVER RESIN}

Savannah River Resin is a resorcinol formaldehyde resin developed at the SRS and available commercially from Boulder Scientific Company in quantities sufficient for use in the CRD system. SRR, which has an estimated cost of $\$ 16 / \mathrm{lb},{ }^{7}$ is currently undergoing laboratory tests at SRS, ${ }^{8}$ ORNL, ${ }^{9,10}$ and Hanford. ${ }^{5}$ Tests have shown that the resin removes cesium from waste solutions at $\mathrm{pH}$ values as low as 8; however, the ion-exchange capacity decreases as the $\mathrm{pH}$ drops below $134^{4,11}$ The SRR has been reported to work best at a $\mathrm{pH}$ range from 12 to $14 .{ }^{4}$ Since this is the approximate $\mathrm{pH}$ range within the MVSTs, $\mathrm{pH}$ adjustment of the feed to the CRD may not be necessary if SRR is used. 
Small column tests at ORNL using simulated wastes have demonstrated that the resin's effectiveness in removing cesium is practically independent of the sodium concentration, but it decreases as the potassium salt concentration increases. The results of increasing potassium concentrations can be seen graphically from data presented in Fig. 1..$^{12}$ At potassium concentrations of $0.5 M, 0.25 M, 0.1 M$, and $0.052 M$, approximately $220,410,900$, and 1600 bed volumes could be expected prior to $50 \%$ breakthrough, respectively. The potassium concentration in the MVST supernates ranges from approximately $0.25 M$ to $0.5 M$, indicating approximately 350 bed volumes of supernate could be treated prior to $50 \%$ breakthrough. These tests using simulated MVST feeds containing a potassium concentration of $0.25 \mathrm{M}$ also indicated that $1 \%$ breakthrough occurred at approximately 40 bed volumes with a $K_{d}$ of $\sim 750 .^{12}$ In small column studies at SRS using a simulated Hanford $101 \mathrm{AW}$ feed, 50\% breakthrough occurred after processing $\sim 100$ bed volumes of liquid. This simulant contained a potassium concentration of $\sim 0.8 \mathrm{M}$.

Actual MVST supernate has been used in batch tests by Collins et al. ${ }^{9}$ to measure the effects of potassium and cesium on the sorption of cesium by SRR. Cesium sorption isotherms for MVST W-25 supernate gave cesium loadings of about 2 meq $/ \mathrm{kg}$ of SRR for cesium concentrations in the supernate of approximately $1 \times 10^{-3} \mathrm{meq} / \mathrm{L}$ (the approximate total cesium concentration in the supernate). This indicates that if full loading of the resin could be achieved, $1 \mathrm{~kg}$ of resin could 


\section{Cesium Ion-Exchage Tests on SRS Resin}

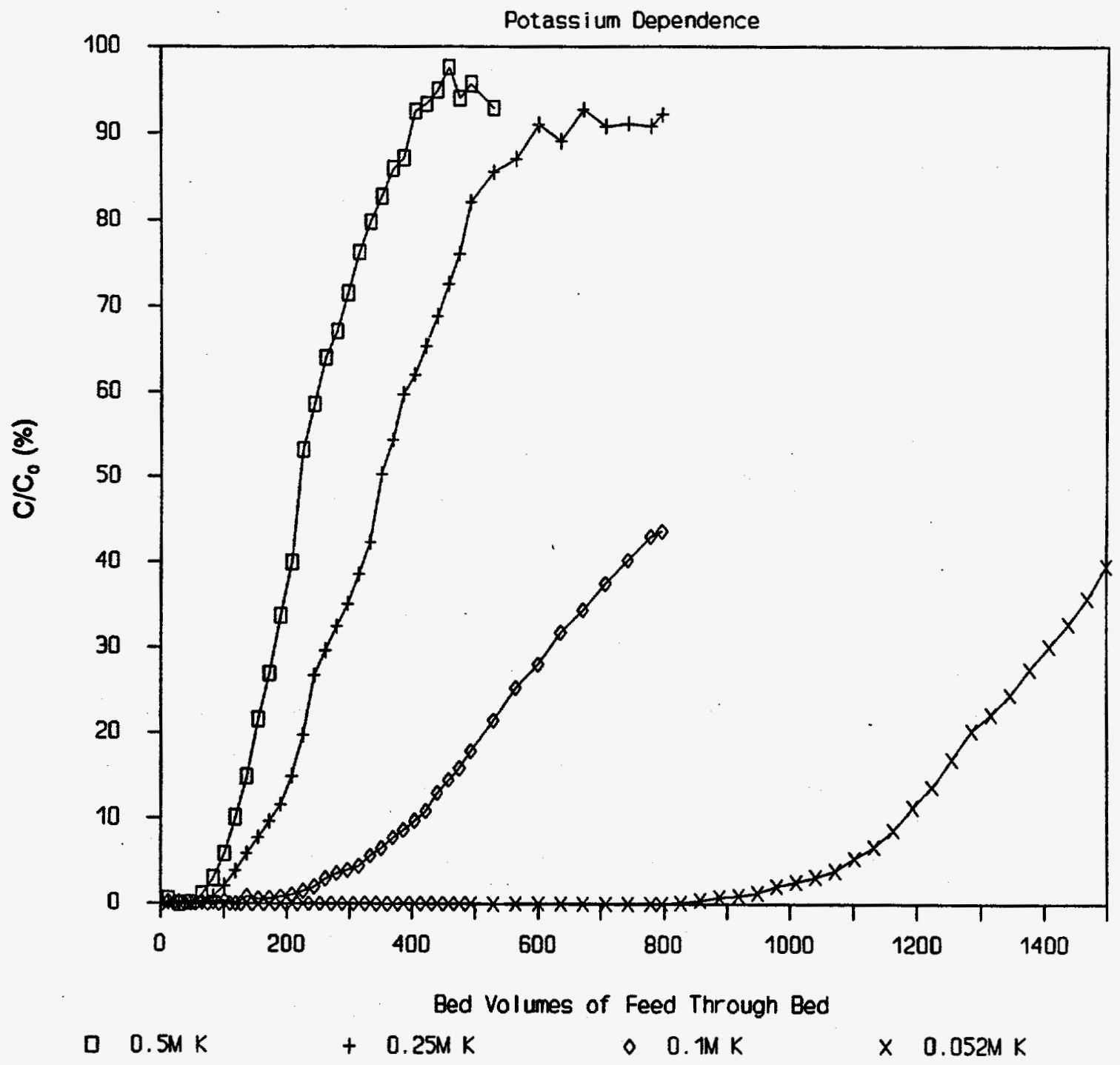

Fig. 1. Effects of potassium on cesium breakthrough curves for Savannah River Resin. 
remove the cesium from $2000 \mathrm{~L}$ of supernate. Thus a minimum of $33 \mathrm{~kg}$ of resin would be required to process $\sim 95,000 \mathrm{~L}(25,000 \mathrm{gal})$ of W-25 supernate.

However, significantly more resin will be required since full loading is not expected to be achieved. Bench-scale column studies using actual MVST waste is planned for FY 1995 (OR-132008-G, Comprehensive Sludge/Supernate Hot Cell Studies, and OR-132008-E, Hot Demonstration of Proposed Commercial Nuclide Removal Technology) to determine the cesium loading that can be expected in columns. ${ }^{13}$ These data will be used to assist in the design of the full-scale CRD system. Column tests have also been performed with SRR using actual radioactive waste generated from newly generated aluminum decladding operations at the Radiochemical Engineering Development Center (REDC) at ORNL. ${ }^{14}$ In tests using 3-in.-diam. columns containing $580 \mathrm{~g}$ of 40 to 60 mesh resin, breakthrough occurred in 85 to 92 column volumes and the resin capacity was $\sim 350 \mathrm{meq} / \mathrm{kg}$ of resin. These wastes contained high concentrations of aluminum and sodium hydroxide $\left(1.14 \mathrm{M} \mathrm{NaAlO}_{2}\right.$ and $\left.2.0 \mathrm{MNaOH}\right)$ and no potassium. ${ }^{14}$

Tests have been done by Bibler on the stability of the resin during storage with and without the presence of radioactivity. ${ }^{8}$ Samples of resin stored for a period of 5 years in drums as delivered from the supplier have shown a decreased capacity for cesium removal. This has been determined to be due to storage of the resin in contact with caustic used in the production of the SRR. The shelf life can be improved by washing the $\mathrm{KOH}$ from the resin before storage. Radiation levels up 
to $10^{8} \mathrm{rad}$ did not alter the performance of the resin for cesium removal. Gas generation as a result of decomposition of the resin was observed with radiation exposure.

A large skid-mounted ion-exchange demonstration (SKID) unit is being set up at Savannah River to test the hydraulic properties of SRR using non-radioactive, simulated supernate of the type stored at Savannah River, Hanford, and ORNL. ${ }^{15}$ The system, which was procured from British Nuclear Fuels, LTS, consists of three resin columns and ancillary equipment. The columns have an empty bed volume of $829 \mathrm{~L}$ ( $219 \mathrm{gal})$ each, and the system is designed to operate at 10 bed volumes per hour $(12.6 \mathrm{gpm})$ at a temperature of $35^{\circ} \mathrm{C}$. Approximately $63 \mathrm{ft}^{3}$ of -20 to +50 mesh SRR has been procured from Boulder Scientific Company for the column tests; however, operation of the unit has not yet been started due to funding limitations.

SRR can be regenerated with nitric, formic, or hydrochloric acid. Regeneration tests have been done with nitric acid concentrations up to $1 M$ by Bibler. ${ }^{8}$ The use of nitric acid at concentrations $>1 \mathrm{M}$ is not recommended because of reaction of the resin with the acid. The resin slowly dissolves in $3 M$ nitric acid. The estimated resin life is 6 to 10 regeneration cycles. ${ }^{15}$ Brunson et al. have regenerated SRR with $2 M$ hydrochloric acid. ${ }^{14}$ 
SRR is considered a primary candidate for use with the CR system due to its superior loading capacity over Duolite CS-100 and because of the interest in its use by other DOE facilities.

\subsection{CRYSTALLINE SILICOTITANATE (CST)}

CST is being developed through a joint effort between Sandia National Laboratory and Texas A\&M University. At the present time, it is available in the form of a very fine powder, but an engineered form suitable for use in columns is expected to be available in 1995 at a cost of $\$ 100$ to $\$ 150$ per pound. ${ }^{7}$ It is expected that quantities of the engineered form suitable for small column tests should be available in early 1995 and that substantial quantities should be available by the summer of $1995 .{ }^{16}$ Since the material is in the early stages of development, patent considerations have prevented release of detailed information regarding the material; however, some information regarding the product has been released by Sandia National Laboratory. A small quantity of CST in the form of a fine powder was also made available to ORNL for testing. Information from Sandia indicates that CST sorbs cesium strongly across a wide $\mathrm{pH}$ range and that it has good chemical and radiation stability. ${ }^{6}$ In batch tests conducted at ORNL by Collins et al. ${ }^{9}$ using actual MVST supernate, distribution coefficients ranging from 451 to $958 \mathrm{~mL} / \mathrm{g}$ were obtained. The distribution coefficient was not significantly affected by the cesium or potassium concentrations. The cesium loading was 
shown to be dependent on the cesium concentration in the supernate (both radioactive and stable). At the total cesium concentration in MVST Tank W-25 supernate $\left(1.4 \times 10^{-6} \mathrm{M}\right)$, the maximum loading that was achieved at equilibrium was about $8 \mathrm{meq} / \mathrm{kg}{ }^{9}$ Based on these data, a minimum of $\sim 17 \mathrm{~kg}$ of CST would be required to process 25,000 gal of typical MVST supernate. However, this data is based on batch tests with fine powders because an engineered form has been unavailable for testing. The engineered form of CST is expected to contain inert binders which may lower the loading capacity. Also, the larger particle size may decrease the uptake rate of the cesium. For these reasons, it is expected that a substantially larger quantity of CST will be required for column operation. It should also be noted that CST elution with acid is not practical and the loaded CST must be disposed of directly or incorporated into another waste form such as glass for disposal.

CST is considered to be a primary candidate for use in the CRD system due to their stability and relatively good loading characteristics. Bench-scale tests with an engineered form of CST would be required to provide data necessary to design the full-scale CRD system. 


\subsection{POTASSIUM COBALT HEXACYANOFERRATE}

Insoluble hexacyanoferrate compounds, produced by reaction of soluble ferrocyanides (such as sodium or potassium ferrocyanides) with salts of divalent transition metals (such as $\mathrm{Co}, \mathrm{Ni}, \mathrm{Cu}$, or $\mathrm{Zn}$ sulfates or nitrates), are very effective in removing cesium, strontium, transuranics, possibly technitium, and cobalt from radioactive waste. ${ }^{17}$ Cesium is primarily removed by ion exchange with the sodium or potassium in the hexacyanoferrate, although sorption and other reactions may also occur.

Fine sodium nickel hexacyanoferrate particles produced by the reaction of nickel sulfate with sodium ferrocyanide were used at Hanford from about 1950 to 1957 to precipitate cesium from the supernate in some of the waste storage tanks. ${ }^{18}$ The treatment was used to remove cesium from the supernate to permit disposal as low-activity waste in cribs and trenches. In recent years there has been concern that excessive changes in temperature could occur in some of the tanks as a result of exothermic reactions of the ferrocyanide compounds with nitrates. This has been declared an unresolved safety issue because postulated accident scenarios are not covered by the existing safety documentation. Thermodynamic and kinetic studies have indicated that ferrocyanide wastes cannot create a hazardous reaction in many of the tanks and that in the remaining tanks the reaction will not occur if 
the tanks contain 12 to $15 \%$ water. The results indicate that the potential risk is considerably less than postulated earlier. ${ }^{18}$

Conditions that could produce a hazardous reaction of nitrates with ferrocyanides can be avoided when the cesium removal operation is performed in columns or in batch process vessels. This would allow the nitrates to be washed from the hexacyanoferrate before it is removed from the process vessel, thus alleviating the problem. However, because of previous concerns regarding the potential for a hazardous exothermic reaction between the nitrates and ferrocyanides, ferrocyanides may not be considered acceptable for use at Hanford and SRS.

The proposed Waste Handling and Packing Plant for processing MVST waste included the addition of fine sodium nickel ferrocyanide powder to the waste as a process step for cesium removal. ${ }^{19}$ The use of fine hexacyanoferrate particles either added to process vessels or formed by precipitation in a process vessel containing supernate could be used in the CRD. Fine powder generally gives higher loading and faster reaction kinetics than the use of granular particles in packed beds. However, the requirements for relatively large mixing tanks, remotely operated filters, and the slurry handling requirements make the system significantly more complex than the use of packed columns. Therefore, a ferrocyanide slurry process is not considered an attractive alternative for the demonstration. 
Several ferrocyanide compounds have been used in the form of fine powders for cesium removal; however, only potassium cobalt hexacyanoferrate, $\mathrm{K}_{2} \mathrm{CoFe}(\mathrm{CN})_{6}$, has been made into a granular form suitable for use in columns. Since a packed bed system will be much easier to operate, potassium cobalt hexacyanoferrate is the primary ferrocyanide compound considered for use in the CRD.

Granular potassium cobalt hexacyanoferrate $(\mathrm{KCoCF})$ in packed columns has been used successfully on a plant scale in Finland to remove cesium from waste solution generated by reactor operation. ${ }^{20}$ Cesium was removed from 66,000 gal of evaporator concentrate using three columns, each with a volume of $8 \mathrm{~L}$. The waste solution contained approximately $3.0 \mathrm{M}$ sodium, $0.2 \mathrm{M}$ potassium , $0.7 \mathrm{M}$ borate, and $0.7 \mathrm{M}$ nitrate. The $\mathrm{pH}$ was lowered from 13.7 to 11.5 with nitric acid and filtered to remove particles $>0.1$ microns prior to processing through the columns. Volume reduction factors (volume of liquid/volume of ion-exchange material) of over 10,000 were achieved at cesium decontamination factors of about 2,000. The granular KCoCF used in this operation was supplied by IVO International, Ltd., in Helsinki, Finland. An ion-exchange column (14-cm diameter by $57 \mathrm{~cm}$ long) containing $8 \mathrm{~L}(\sim 4.5 \mathrm{~kg})$ of granular KCoCF is available from IVO International for approximately $\$ 25,000 .^{21}$ Smaller quantities are available at approximately \$5 per gram from the Finnish Nuclear Waste Technology Group (the U. S. supplier of IVO's resin), although they prefer that a representative from their company add the material to the column. ${ }^{22}$ Collins at ORNL has also 
demonstrated the production of granular KCoCF that is suitable for use in ionexchange columns in small-scale equipment that could potentially be used to produce the quantities of material needed for the CRD. ${ }^{23}$

Batch tests have been performed by Collins et al. ${ }^{9}$ using $\mathrm{KCoCF}$ with supernate from MVST Tank W-25. Distribution coefficients ranging from 26,000 to 46,000 , which are much higher than any other resin tested, were obtained. These tests indicate that a minimum of $\sim 3 \mathrm{~kg}$ of $\mathrm{KCoCF}$ would be required to remove the cesium contained in 25,000 gal of typical MVST supernate: Since this data is from batch equilibrium studies, larger volumes of $\mathrm{KCoCF}$ would probably be needed for the flow rates and residence times desired for column operation.

Tests have shown that hexacyanoferrates are suitable for use in solutions with $\mathrm{pH}$ values ranging from approximately 2 to 12 . In laboratory tests, Collins et al. produced a granular KCoCF stable enough to treat supernate from MVST W-25 having a pH of 12.6. ${ }^{9}$ However, $\mathrm{KCoCF}$ has been shown to begin to dissolve or decompose at $\mathrm{pH}$ values greater than 12. An example of a decomposition reaction that might occur is

$\mathrm{Cs}_{2} \mathrm{CoFe}(\mathrm{CN})_{6}+6 \mathrm{NaOH}-2 \mathrm{CsOH}+\mathrm{Co}(\mathrm{OH})_{2} 1+\mathrm{Fe}(\mathrm{OH})_{2} \downarrow+6 \mathrm{NaCN}$. 
The $\mathrm{pH}$ of the supernate in the Melton Valley Storage Tanks was generally in the range of 9.1 to 13.3 when sampled in $1989 .{ }^{24}$ However, the addition of newly generated waste and the addition of carbonates to the tank as a result of air sparging may have resulted in changes in $\mathrm{pH}$ since that time. The MVSTs, as well as the Hanford waste tanks, may require $\mathrm{pH}$ adjustment if $\mathrm{KCoCF}$ were to be used to remove cesium. Adjustment of the $\mathrm{pH}$ could possibly be done in the feed tank for the CRD system without requiring an additional tank; however, $\mathrm{pH}$ adjustment may precipitate solids, which could make additional filtration equipment necessary. This is particularly true if significant quantities of aluminum compounds were present in the supernate.

Studies of the effects of gamma radiation by Lehto and Szirtes ${ }^{25}$ indicate that KCoCF can withstand very high radiation doses (up to $5 \mathrm{MGy}$ ) with practically no change in structure. Hexacyanoferrates decompose at elevated temperatures. $\mathrm{KCoCF}$ loses water of hydration at $170^{\circ} \mathrm{C}$ and begins to decompose above $230^{\circ} \mathrm{C}$. The cyanide groups evaporate in the range of 230 to $350^{\circ} \mathrm{C}$, and solid products of potassium carbonate, iron, and cobalt oxides are formed. ${ }^{26}$ The thermal decomposition properties of $\mathrm{KCOCF}$ are important for storage and disposal if the material is to be further processed at high temperatures to incorporate into glass. 
$\mathrm{KCoCF}$ is considered to be a primary candidate for use in the CRD system due to its very high loading capacity for cesium. Concerns regarding the potential for a hazardous exothermic reaction between $\mathrm{KCoCF}$ and the nitrate in the wastewater will have to be alleviated before this material could be used at Hanford or SRS.

\subsection{PILLARED CLAY}

Work is in progress by Allied Signal to develop a high-porosity engineered form of pillared clay. ${ }^{6}$ Pillared clay has been shown to have good chemical and radiation stability; however, development work needs to be done to overcome problems associated with selectivity to potassium. ${ }^{6}$ Pillard clay is not considered to be a primary candidate for use in the CRD.

\subsection{AMMONIUM MOLYBDOPHOSPHATE}

Ammonium molybdophosphate has been used to remove cesium from PUREX solutions with $\mathrm{pH}$ values ranging from that of concentrated nitric acid up to a $\mathrm{pH}$ of 9; however, AMP should not be used at a $\mathrm{pH}>6$ because it decomposes at these higher $\mathrm{pH}$ values. Adjustment of the $\mathrm{pH}$ of the supernate in the CRD system would be necessary if AMP were to be used. However, the ability of AMP to remove cesium from acid solutions makes it a candidate for removal of cesium from acid eluents should regeneration of the CRD resin be demonstrated. A large 
excess of sodium ions should not have an impact on the retention capacity of AMP. ${ }^{27}$ It should also be noted that at the present time, AMP is available only in the form of a fine powder, which is not suitable for use in columns.

\subsection{EMBEDDED MEMBRANE TECHNOLOGY (EMT)}

The 3M company has developed a method for binding particles into a porous membrane suitable for use as an ion-exchange media. ${ }^{6}$ This method may be helpful in preparing materials for column use that are difficult to prepare in an engineered form by other methods. Dr. Gary L. Goken of 3M stated that particles of materials (such as KCoCF, CST, AMP, crown ethers, etc.) on the order of 10 to 20 microns can be bound together with Teflon, Kevlar, and other plastics and be made into pleated filters that resemble water filter cartridges. ${ }^{28}$ He indicated that $3 \mathrm{M}$ is interested in testing their embedded membrane material in the CRD.

However, Embedded Membrane Technology (EMT) is not considered to be a primary candidate for the CRD because the technology has not been adequately developed at this time.

\section{FACILITY ALTERNATIVES}

The basic facility requirements for placement of the CRD system include the following: (1) the facility must provide secondary containment for ion-exchange 
resin loaded with cesium and for radioactive supernates to be processed, (2) the facility must be capable of receiving and returning supernate to and from the Melton Valley Storage Tanks (MVSTs) or possibly one of the Evaporator Service Tanks, and (3) the facility must be capable of handling casks for removal and transport of resin loaded with cesium. Upgrade of the facility to meet the above requirements would be considered acceptable as long as the cost and schedule requirements for operation in FY 1996 can be met.

Four facilities at ORNL were evaluated as potential sites for housing the CRD. The facilities included the following:

Building 7877, Liquid Low-Level Waste Solidification Facility Building 7860, New Hydrofracture Facility Building 3517, Fission Product Development Laboratory Building 7930, TURF (Thorium-Uranium Recycle Facility)

Other hot cell facilities at ORNL, such as those located in Buildings 3019, 3047, and 3525 , were discussed as potential sites for the demonstration system; however, they were considered less desirable for placement of the CRD system and were not subjected to a detailed evaluation. However, it is possible that some of these hot cell facilities might be suited for temporary storage of loaded ion-exchange 
columns. A description of the four facilities evaluated for placement of the CRD system follows.

\subsection{BUILDING 7877, LIQUID LOW-LEVEL WASTE SOLIDIFICATION FACILITY}

Building 7877 is a metal building approximately $33 \mathrm{ft}$ wide by $60 \mathrm{ft}$ long by $35 \mathrm{ft}$ high which is located adjacent to the concrete enclosure containing the MVSTs. A floor plan for the building is presented in Fig. 2. The primary function of the building is to provide containment for mobile equipment that is periodically brought into the building on flatbed trailers for solidification of batches of supernate in concrete. A remote panel board for monitoring the waste solidification operation is located in an adjacent building (7863). This location may also be suitable for locating remote monitoring instruments for the CRD. Building 7877 contains a HEPA ventilation system as well as a pump module used to transport supernate from either MVST W-29 or W-30 into the building for the solidification campaigns. The pump draws liquid from the approximate center of the tanks to prevent settled solids from being removed from the tanks. Liquid can also be sent in reverse through the same line back into either tank. The building is equipped with a 5-ton-capacity overhead crane with at 25 -ft hook height. Access to the building is through personnel doors and two rollup doors for vehicle entry. It should also be noted that Engineering personne ${ }^{29}$ have indicated that the 

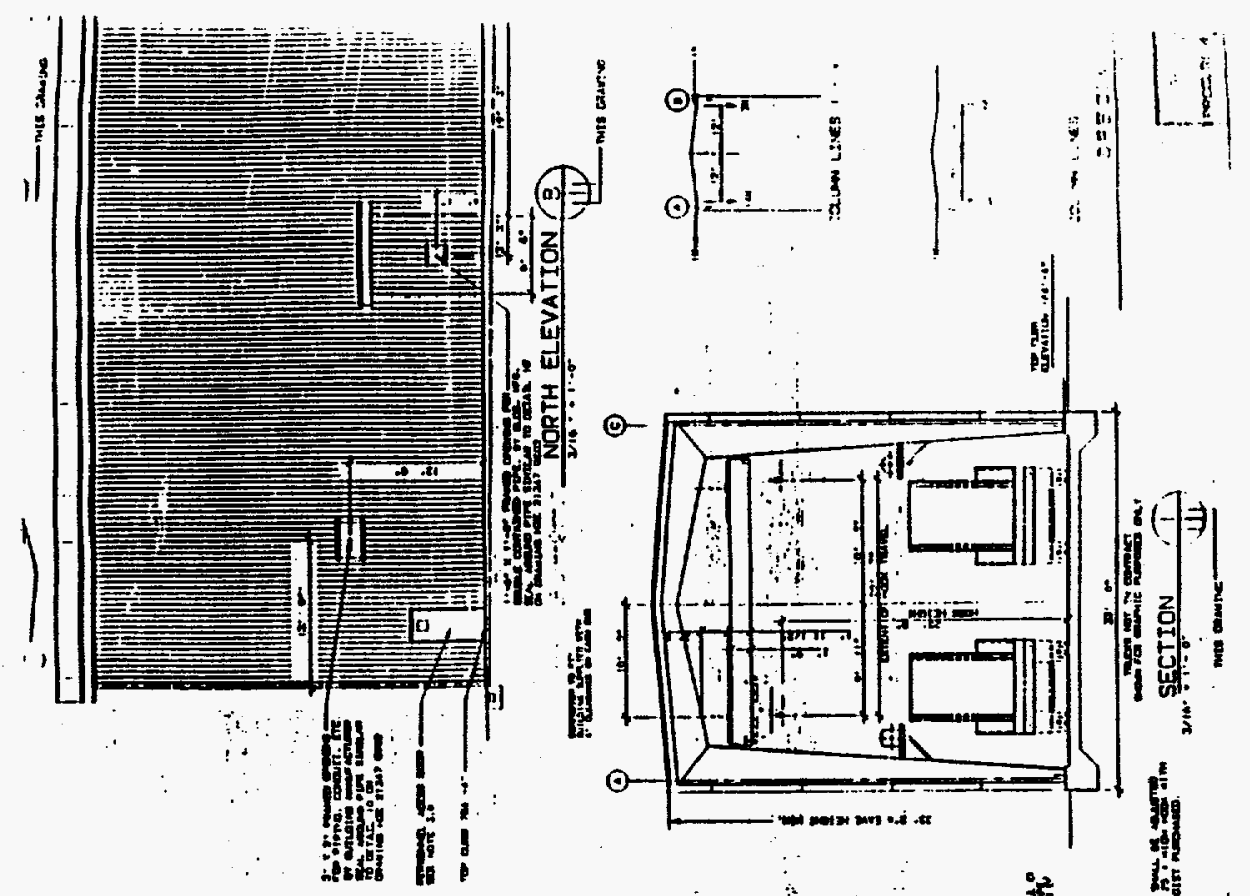

尽

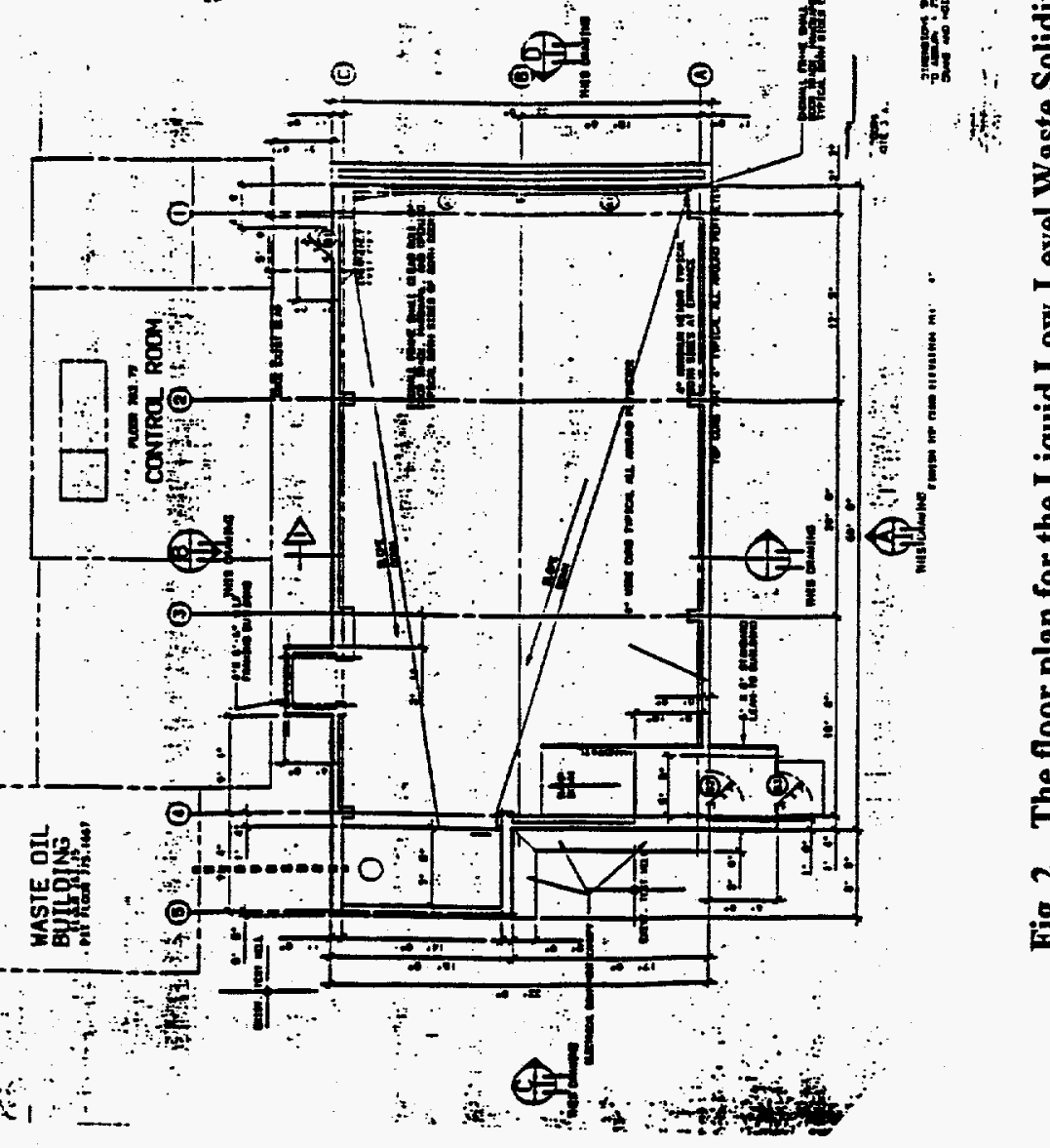


existing Safety Study for the LLLW Solidification Facility ${ }^{30}$ can be modified to include installation and operation of the CRD system in Building 7877 without making major modifications to the document.

In the past, solidification campaigns have been conducted approximately once per year, and each campaign has required $\sim 3$ months for completion. The building is also scheduled to be used for mobile equipment for the Out-of-Tank Evaporation Demonstration (OTED) in FY 1995. Use of Building 7877 for the CRD system is possible; however, installation and operation of the unit would have to be scheduled around the OTED and future solidification campaigns. The LLLW Solidification Facility appears to meet all the basic requirements for housing the CRD unit for processing MVST supernate, with only minimal modifications required. Use of the facility also offers the advantage that some of the equipment and documentation needed for the OTED system might also be useful for the CRD.

\subsection{BUILDING 7860, THE NEW HYDROFRACTURE FACILITY}

The New Hydrofracture Facility (NHF), which is located directly across the street from the MVSTs, was used for disposal of low-level waste through underground injection from 1982 until 1984. Changes in regulations and operational problems discovered in 1984 preclude any further use of the facility for underground 
injections. The hot cells in the building have remained essentially unused since shutdown in 1984.

The NHF building consists of equipment rooms, office areas, change rooms, and hot cells. A floor plan of the building in given in Fig. 3. The three hot cells in the facility are the well cell, the pump cell, and the mixing cell. The walls and ceiling of the cells are made of $21 / 2$-ft-thick reinforced concrete. The cells are ventilated through HEPA filters. All the cells are contaminated from previous operations, and there is no secondary containment around the cells. ${ }^{31}$ The general radiation background in the well cell, which contains the well head, is approximately $200 \mathrm{mR} / \mathrm{h}$, with spots reading up to $2 \mathrm{R} / \mathrm{h}$. The mixing cell, which contains hoppers and mixing tubs, has approximately the same level of contamination as the well cell. The pump cell contains the pump suction and manifolds and has a background reading from 44 to $50 \mathrm{mR} / \mathrm{hr}$. Equipment in the cells is visible through shielded viewing windows; however, the cells do not have manipulators or manipulator ports for use in conducting remote operations inside the cells. Access to the cell is through roof plugs at the tops of the cells.

Existing pipelines run from the MVSTs to Building 7860; however, all of the lines originate at the bottom of waste tanks. Since all of the tanks have a sludge layer on the bottom, the existing piping would not be suitable for delivering clear supernate for the CRD system without considerable modification. Removal of the 


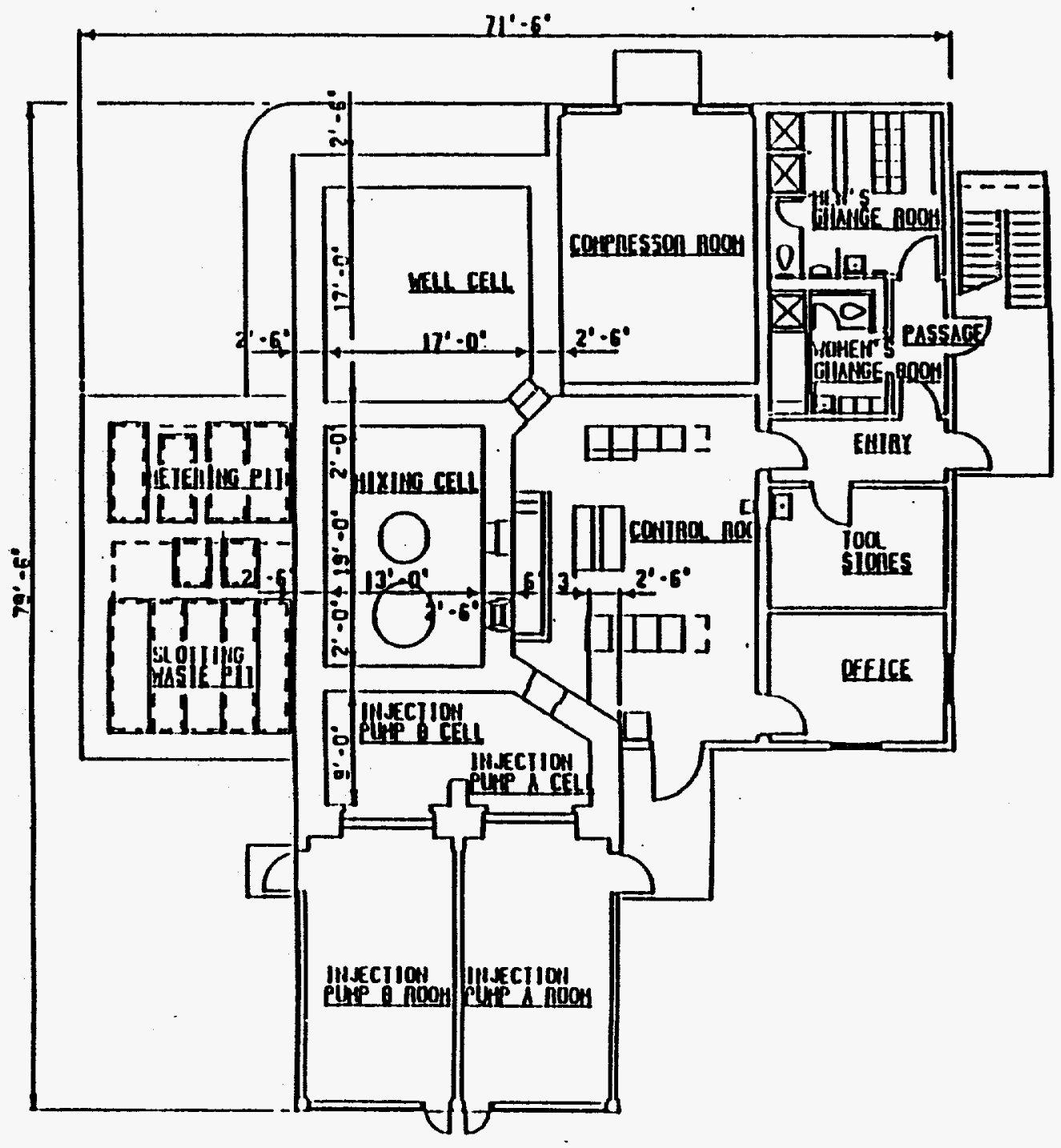

Fig. 3. The floor plan for the New Hydrofracture Facility (Building 7860). 
existing equipment from the cells, decontamination of the cells, modifications to provide for remote operation, and piping modifications necessary to get clear supernate into the hot cells would require considerable time and expense. It is also expected that major modifications to the final Safety Analysis Report (approved in May 1982) would be required prior to operation of the CRD system in the facility ${ }^{32}$ It is not expected that the modifications required for use of Building 7860 could be performed within the budget or time frame required for the cesium removal demonstration.

\subsection{BUILDING 3517, FISSION PRODUCT DEVELOPMENT LABORATORY}

The Fission Product Development Laboratory was operated from 1958 to 1975 to recover long-lived fission products from aqueous waste. In later programs, concentrates of ${ }^{137} \mathrm{Cs},{ }^{90} \mathrm{Sr}$, and ${ }^{144} \mathrm{Ce}$ were shipped from Hanford for fabrication into heat sources. Operation of the facility was discontinued about 1990 . The building is currently used for storage of ${ }^{137} \mathrm{Cs}$ and other isotopes remaining from the processing operations. Some of the equipment has been dismantled, but much of the building is still operable. Building 3517 is currently on the list for shutdown, and DOE approval would be required for use of the building for operations such as a CRD. It is expected that use of the building for the CRD would be approved; however, other projects that might have higher priority are also considering use of the building. ${ }^{33}$ 
Building 3517 is located near the intersection of White Oak Avenue and Third Street near the Rad Waste Evaporator System in the main ORNL complex. A floor plan for the building can be seen in Fig. 4. The building contains hot cells, operating areas, service areas, and office areas. The main cell block consists of 15 process and manipulator cells. Attached to the main cell block are two additional manipulator cells and two service cells. Four tank-farm cells are located underground adjacent to the building. ${ }^{34}$ Most of the cells are lined with stainless steel and vented through HEPA filters to the 3039 stack. Services such as steam, cooling water, process off-gas, and electrical power are provided to the cells. Radioactive material can be transferred to cells 10 and 15 from bottom discharge casks. The port into cell 10 is 13 in. in diameter, and the port into cell 15 is large enough for a 55-gal drum. Manipulators in the cells can handle loads up to $25 \mathrm{lb}$, and some of the cells are equipped with hoists for handling heavier loads. The building crane has a 20-ton load capacity. Cleaning would be required for entry into the cells for modifications.

The facility has a Safety Analysis Report (SAR) and is currently approved for the storage of up to $250,000 \mathrm{Ci}$ of ${ }^{137} \mathrm{Cs}$. The existing SAR would likely simplify the preparation and approval of safety and other documentation required for operation of the CRD in the facility. 

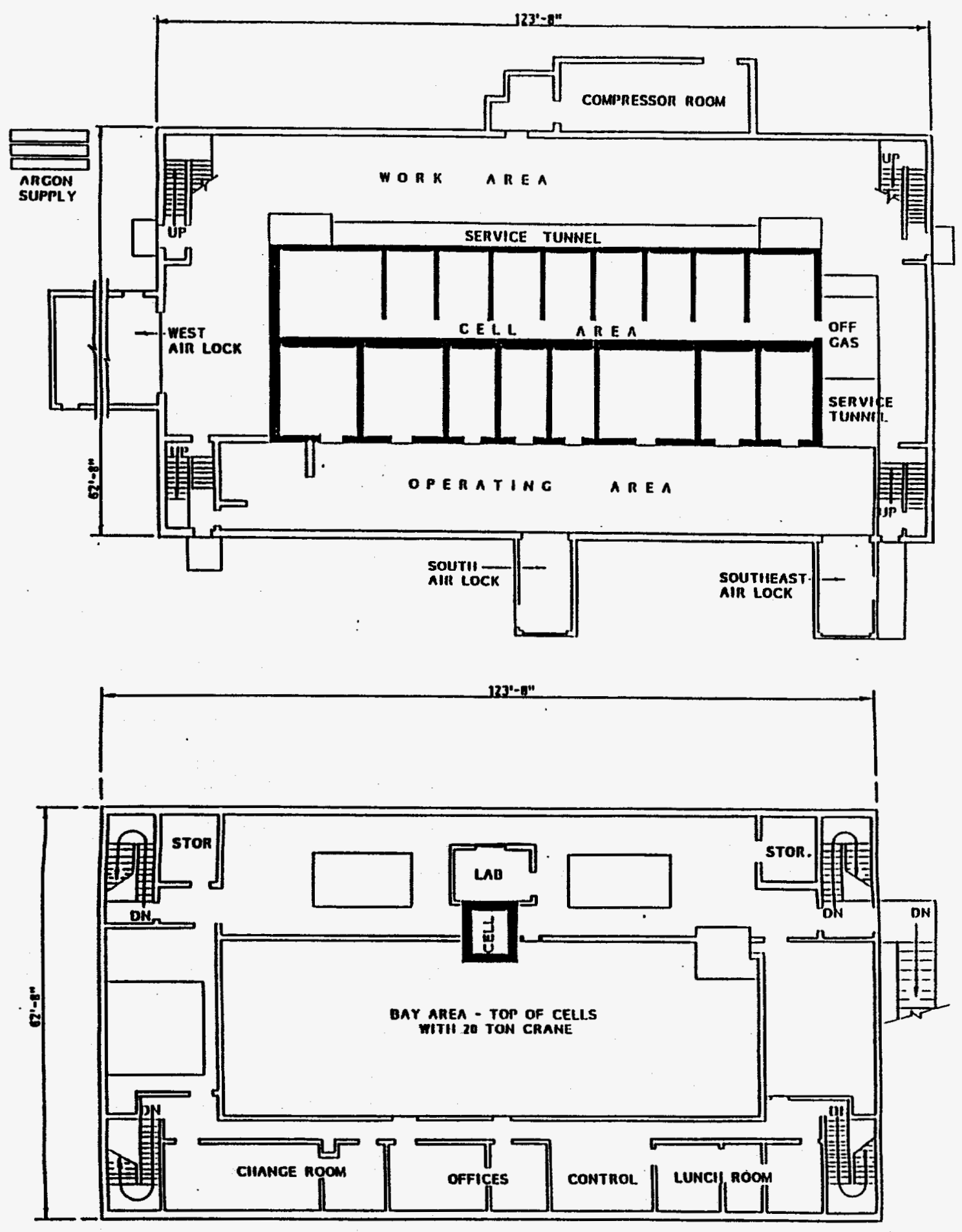

Fig. 4. The floor plan for the first floor and the transferse section of the Fission Product Development Laboratory (Building 3517). 
The close proximity of Building 3517 to the LLLW evaporator would be helpful to some extent in providing a pipeline from the MVSTs to the facility since a pipeline exists for sending liquid waste to the evaporator. However, an extension of the pipeline from the evaporator facility to Building 3517 or the use of a transport truck would be required. Transport of MVST supernate to Building 3517 was addressed in a previous study. ${ }^{35}$ The pipeline for transferring LLLW waste from the evaporator facility (Building 2531) to the Melton Valley Storage Tanks comes within about $200 \mathrm{ft}$ of Building 3517 . Connecting to the line would require that a section of doubly contained pipe be installed between Building 3517 and Valve Box 6. Approval and installation of the pipeline are estimated to require 2 to 4 years. ${ }^{35}$ Modifications might also be required at the MVST to provide lines to supply supernate with no solids present. Transport of supernate to the facility might be possible using a shielded tanker truck (French Cogema Truck) that is being procured; however, this option has considerable uncertainty because of the approvals required and the availability of the truck at the time needed.

Given the time required for installation of underground lines and the uncertainties associated with the use of a shielded tanker for transporting radioactive waste to Building 3517 , it is unlikely that the facility could meet the schedule requirements necessary of the CRD. However, the facility has good potential for temporary storage and repackaging operations for loaded resins from the CRD system should 
those be necessary. The use of the building for this purpose will require DOE approval and possibly some relatively minor modifications.

\subsection{BUILDING 7930, THORIUM-URANIUM RECYCLE FACILITY}

The Thorium-Uranium Recycle Facility (TURF) is a hot cell facility located adjacent to the Radiochemical Engineering Development Center (REDC). The building houses hot cells, operating areas, and office areas, as shown in Fig. 5. The hot cells consist of two large manipulator cells (approximate dimensions $33 \times 20 \times 24 \mathrm{ft} \mathrm{high)} \mathrm{and} \mathrm{two} \mathrm{smaller} \mathrm{cells} \mathrm{(approximate} \mathrm{dimensions} 16 \times 20 \times 30$ $\mathrm{ft}$ high). Radioactive material may be brought into or removed from the cells by carriers through roof plugs in the top of the cells. The exhaust from all cells is vented through HEPA filters to the High Flux Isotope Reactor (HFIR) stack. Drain lines from the cells go to waste tanks that can be discharged through existing underground lines to the LLLW evaporator. Two of the cells (one large and one small) are used for processing californium. The remaining two cells are not in use and would possibly be available for the CRD project.

The use of Building 7930 for the CRD would require cell modifications, inspection, possible maintenance of the underground lines from the cells to the LLLW evaporator, and extensive revisions to the existing facility SAR. Also, there are no pipelines in the area that could be used for transporting supernate 

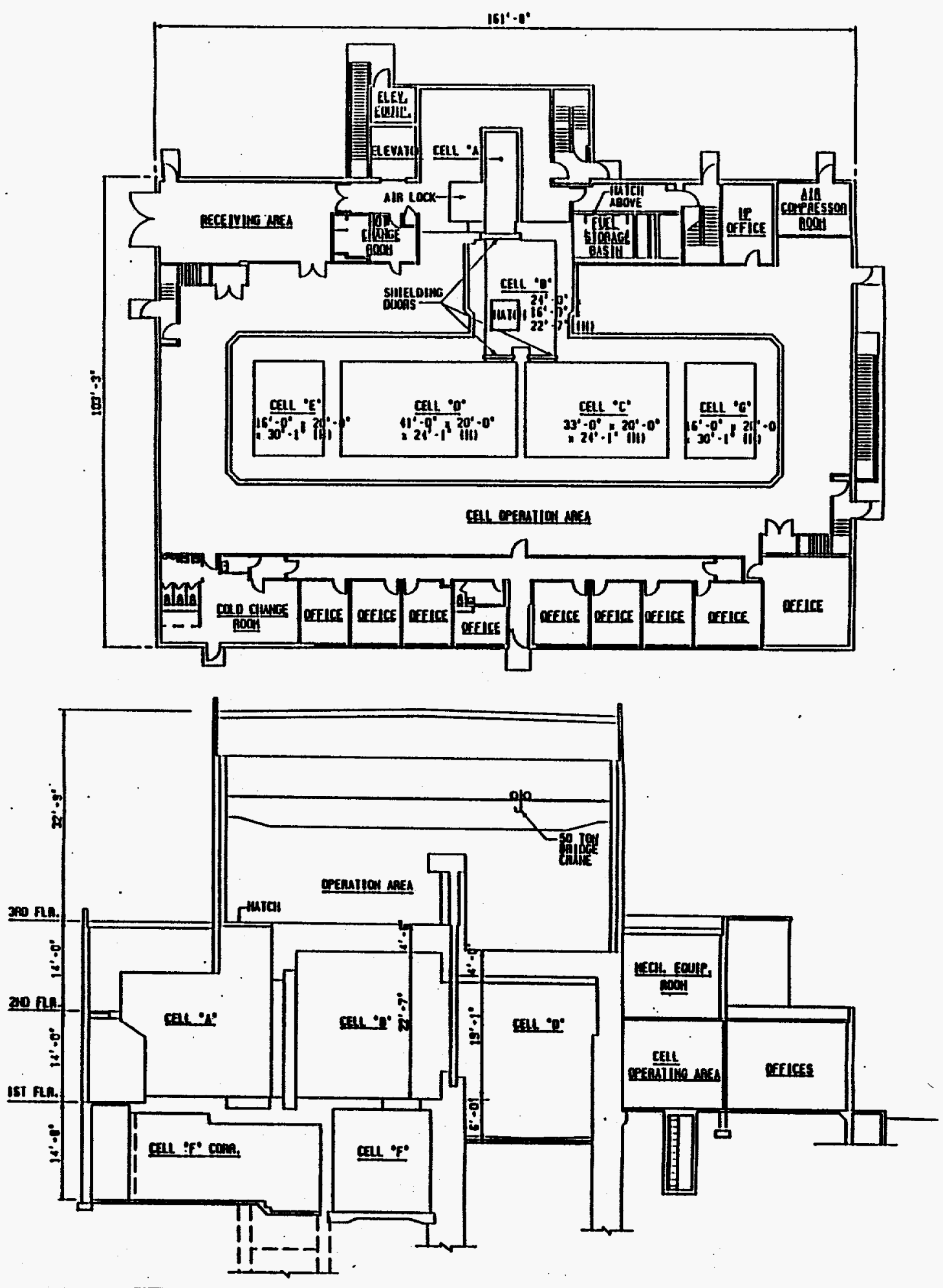

Fig. 5. The floor plan for the first floor and the transverse section for the Thorium-Uranium Recycle Facility (Building 7930). 
from the MVST to the facility, and there are no provisions for unloading supernate transported by shielded transport truck. Installation of a pipeline from the MVST to Building 7930 would be prohibitively expensive and time-consuming for the CRD project. Transportation of supernate by shielded truck is not considered to be a viable alternative due to uncertainties in the availability and approval for the use of the truck.

\section{PROCESS Alternatives}

Process alternatives considered for the CRD included the following: (1) the MVST chosen for treatment in the CRD, (2) the mode of operation, (3) process flow rates, (4) resin regeneration, and (5) shielding requirements. These are discussed in detail below.

\subsection{THE MVST CHOSEN FOR TREATMENT IN CRD}

The MVST chosen for use in the CRD will depend on the character of the LLLW in the tank as well as on input from ORNL WMRAD personnel. Of particular concern will be the $\mathrm{pH}$, the nitrate concentration, the sodium concentration, the potassium concentration, and the radionuclide content within the tanks. The MVSTs (and associated evaporator tanks) supernate typically have a high pH (11 to 13). The main dissolved salts are sodium and potassium nitrates. When 
sampled in 1989 , the nitrate concentration in the supernate varied from 3 to $5 \mathrm{M}$, with the average being about $4 M^{24}$ The sodium varied from 2.7 to $4.8 M$, and the potassium concentration varied from 0.2 to $2.0 M .^{24}$ From the 1989 sampling, ${ }^{137} \mathrm{Cs}$ and ${ }^{90} \mathrm{Sr}$ were shown to be the dominant radionuclides in the MVST supernate. At that time, the average ${ }^{137} \mathrm{Cs}$ concentration in the supernate was $1.38 \times 107 \mathrm{nCi} / \mathrm{L}$, with the maximum and minimum concentrations being $5.59 \times$ $10^{7}$ and $5.06 \times 10^{6} \mathrm{nCi} / \mathrm{L}$, respectively. The average ${ }^{90} \mathrm{Sr}$ concentration at that time was $1.48 \times 10^{6} \mathrm{nCi} / \mathrm{L}$, and the concentration ranged from a low of $1.11 \times 10^{4}$ to a high of $4.73 \times 10^{6} \mathrm{nCi} / \mathrm{L}$.

Due to the addition of waste to the MVSTs from the LLLW evaporator, the removal of supernate for solidification campaigns, and the removal of water due to the In-Tank Evaporation Process, the composition within the tanks have changed somewhat since the 1989 sampling. Cesium-137 concentrations as of July 1994 for tanks W-24 through W-31 ranged from $8.7 \times 10^{6}$ to $3.2 \times 10^{7} \mathrm{nCi} / \mathrm{L}$, and the potassium concentrations ranged from 0.22 to $1.5 M^{36}$ Recent measurements of the cesium concentration in MVST tank W-25 have been made by Collins et al. ${ }^{9}$ The sodium and potassium concentrations in W-25 were $3.87 \mathrm{M}$ and $0.36 \mathrm{M}$, respectively. The total concentration of cesium (both radioactive and nonradioactive) in tank W-25 supernate was determined to be $1.4 \times 10^{-6} \mathrm{M}$ $(0.19 \mu \mathrm{g} / \mathrm{mL})$, and the ${ }^{137} \mathrm{Cs}$ activity was $6.8 \times 10^{6} \mathrm{nCi} / \mathrm{L}$. The calculated cesium concentration in all eight of the MVSTs was between 5 and $56 \mu \mathrm{g} / \mathrm{mL}^{3}$. 
Supernate samples from the MVSTs have recently been submitted for analysis in preparation for the OTED; however, results of these analyses were not available at the time of this report. ${ }^{37}$ It is expected that the results from these analyses will be used to assist in the design of the CRD system. Additional sampling and analyses may be necessary prior to conducting the CRD to ensure the character of the waste to be treated has not changed.

\subsection{MODE OF OPERATION}

Two modes of operation have been identified for use in the cesium removal demonstration system: (1) a slurry operation and (2) a packed column operation. Of the three ion-exchange materials considered as prime candidates for the CRD demonstration (i.e., SRR, CST, and KCoCF), only potassium cobalt hexacyanoferrate is considered to have a distribution coefficient sufficiently high enough for use in a slurry process. Any three of the materials could be used in a column operation. The filtration requirements and slurry handling capabilities necessary for a slurry process would tend to complicate the operation of the system and make it more difficult to operate in a radioactive environment. As a result, a packed column operation is preferred. 


\subsection{PROCESS FLOW RATES}

Factors important in determining the design flow rate of supernate through the system include the size of the ion-exchange column, the required residence time within the column, and the time required to process up to 25,000 gal of supernate.

An ion-exchange column with a diameter of $\sim 12$ in. and a resin bed height of $\sim 30$ in. has been chosen for use in the conceptual design of the CRD system. It should be noted that the size of the column could change, depending on the outcome of studies currently planned through task OR-132008-E (Hot Demonstration of Proposed Commercial Nuclide Removal Technology) to produce design data for the CRD system using actual MVST supernate. A carrier located at ORNL would allow a column of the above size to be transported on site at ORNL without having to rent a carrier from an outside vender. This size column would allow up to 25,000 gal of supernate to be treated in a reasonable period. However, changeout of the resin in the column (or replacement of the column with a column containing new resin) would be necessary as the material in the column becomes loaded with cesium. The number of changeouts required would depend on the cesium loading capacity of the material used in the demonstration. 
The minimum flow rate suggested in Perry's Handbook to prevent maldistribution is $1 \mathrm{gpm} / \mathrm{ft}^{2}{ }^{38}$ Using SRR in small columns, Campbell performed tests at superficial velocities of 1.3 and $0.26 \mathrm{~cm} / \mathrm{min}\left(0.33\right.$ and $\left.0.1 \mathrm{gpm} / \mathrm{ft}^{2}\right)$ and suggested a 30-min residence time. ${ }^{38}$ REDC used flow rates from 0.4 to $0.7 \mathrm{gpm} / \mathrm{ft}^{2}$ in a 3-in.-diam column ${ }^{14}$ The SKID ion-exchange unit at Savannah River, which has columns with an empty bed volume of $219 \mathrm{gal}$, was designed for a flow rate of $2.5 \mathrm{gpm} / \mathrm{ft}^{2}$ and a throughput of 10 volumes per hour in columns. ${ }^{38}$ Using a 12-in.-diam column with a nominal flow rate of $1 \mathrm{gpm}$ would give a flow of $1.4 \mathrm{gpm} / \mathrm{ft}^{2}$ with a residence time of $\sim 15 \mathrm{~min}$ (approximately 4 bed volumes per hour). At a nominal flow rate of $1 \mathrm{gpm}, 417 \mathrm{~h}$ or approximately eleven 40 -h work weeks would be required to process up to 25,000 gal. If the process were operated $24 \mathrm{~h}$ per day, approximately 1 month would be required to process that volume. Additional time would be required for such operations as startup, shutdown, filling the feed tank, and change out of ion-exchange resin. If one week were to be allowed for changeout of ion-exchange material, up to an additional 11 weeks would be required for use of the SRR. This would give an estimated time of 15 to 22 weeks to process up to $25,000 \mathrm{gal}$ of supernate. It is expected that a similar time frame would be required for use of CST. Normal operation of the CRD system will require two people to be present for safety reasons.

It should be noted that although the conceptual design of the CRD system is based on a 1-gpm nominal flow rate, the system will have the capability to operate over a 
much wider flow range. Also, the information used in this design is based on information taken from small-scale equilibrium studies. Larger-scale column studies that are to provide design data for the CRD system are to be conducted during FY 1995 (OR-132008-E, Hot Demonstration of Proposed Commercial Nuclide Removal Technology). If these studies warrant, the CRD system flows may be changed.

\subsection{REGENERATION}

Of the resins being considered for use in the CRD, regeneration methods have been developed only for the SRR. Development of regeneration methods for SRR using up to $1 M$ nitric acid are currently being done by Bibler ${ }^{8}$ and Bray ${ }^{39}$ Upflow elution tests in small columns show that $85 \%$ of the cesium, sodium, and potassium ions can be removed simultaneously with $0.5 \mathrm{M}$ nitric acid. ${ }^{8}$ Approximately 20 column volumes of $0.5 M$ nitric acid was required. The SRR slowly dissolves in $3 \mathrm{M}$ nitric acid, and the use of nitric acid concentrations above $1 M$ is not recommended because of deterioration of the resin. ${ }^{40}$ Savannah River Resin loaded with cesium has also been eluted with hydrochloric acid by Brunson et al. ${ }^{14}$ In one test, the bed was completely eluted with 16 column volumes of $2 M$ hydrochloric acid. Bed shrinkage was about $50 \%$ on elution. Formic acid (1 $M)$ has also been used for elution of SRR. ${ }^{40}$ 
One disadvantage of resin regeneration is the quantity of eluent required to regenerate the resin. AEA Technology (formerly the United Kingdom Atomic Energy Authority) has developed a process for electrochemical ion-exchange elution. The process was tested on a bench scale at Pacific Northwest Laboratory as an alternative to acid elution of cesium from loaded ion-exchange resins. Electrochemical elution of loaded SRR resulted in an $~ 70 \%$ reduction in the total waste volume as compared with standard acid elution. ${ }^{41}$

Several possible options exist for demonstration of SRR regeneration of using either standard acid elution or electrochemical elution within the CRD. The resin could be eluted in place, with the eluent going back into the MVSTs. A second option would be for the resin to be eluted in place with the nitric acid/cesium eluent being pumped through a second column containing another ion-exchange media (such as KCoCF or zeolites) to remove the cesium from the eluent. ${ }^{42}$ This method would likely require washing the column before and after elution with water or caustic for $\mathrm{pH}$ control to prevent precipitation of soluble components. A third option would be to transfer the loaded resin column(s) from the CRD system to a hot cell at ORNL or Savannah River for elution tests. Bibler at Savannah River has expressed interest in doing elution tests on loaded columns from the CRD. ${ }^{43}$ 
Regeneration of the resin would significantly increase the complexity of equipment needed as well as the impact of the safety documentation approval requirements and possibly the design of containment facilities for the CRD. Additional tanks, columns, and other equipment would be required. The use of an oxidizing agent such as nitric acid for elution of organic resins would require added safety considerations. The use of hydrochloric acid for elution of the resin bed would require that special materials of construction be used.

\subsection{CRD UNIT SHIELDING REQUIREMENTS}

The radiation shielding requirements for $\mathrm{a}^{137} \mathrm{Cs}$ source similar to that expected for the loaded ion-exchange column in the CRD system were calculated by members of the Computing Applications Division. ${ }^{44}$ Calculations were made at points 24 in. from the center of a 12-in.-diam by 30 -inch-high pipe containing $200 \mathrm{Ci}$ of ${ }^{137} \mathrm{Cs}$ in water attenuated by several different shields. The radiation levels are expected to be directly proportional to the quantity of ${ }^{137} \mathrm{Cs}$ loaded on the resin in each column. The radiation level at the surface of the column with no shielding was calculated to be $563 \mathrm{rem} / \mathrm{h}$. This was attenuated by 3,5 , and $6 \mathrm{in}$. of steel to give radiation levels of 2800,207 , and $53 \mathrm{mrem} / \mathrm{h}$, respectively, at $24 \mathrm{in}$. from the source. Three inches of lead reduced the radiation level at $24 \mathrm{in.} \mathrm{to} 5 \mathrm{mrem} / \mathrm{h}$. Based on the calculations, it is expected that on the order of 6 in. of steel or 3 in. of lead shielding will be required for the CRD system. The existing ORNL carrier has the 
equivalent of about 3 in. of lead, which should be adequate for transporting loaded resin columns. Commercial DOT-approved carriers that are available for transportation of loaded resin columns over public roads may be able to carry several columns at one time.

Calculations were also done to provide an estimate of the radiation level from scatter that might be encountered above ion-exchange columns during the removal operation. ${ }^{44}$ For the calculation, the lid was raised $3 \mathrm{ft}$ above the $200-\mathrm{Ci}$ source, and the radiation levels were calculated at $2,6,10$, and $20 \mathrm{ft}$ from the centerline of the source. The corresponding levels were $67.8,8.8,25$, and $0.4 \mathrm{mrem} / \mathrm{h}$, respectively. It is not expected to be necessary to raise the lid from above the cask during normal operation.

\section{CRD WASTE DISPOSAL ALTERNATIVES}

Process waste from the CRD could include (1) processed supernate, (2) loaded ion-exchange resin(s), (3) contaminated filters, and (4) acid eluent from regeneration of loaded resin(s). The alternatives for disposing, storing, or further handling of these process wastes are discussed below. 


\subsection{PROCESSED SUPERNATE}

Since the CRD system is designed to remove only cesium, the effluent from the process will not meet the waste acceptance criteria for the ORNL Process Waste Treatment Plant (PWTP). The PWTP can accept only very dilute wastewaters with trace quantities of radionuclides. As a result, the supernate must be stored in LLLW storage tanks. Piping currently exists for returning the processed supernate to either W-29 or W-30, which are also the tanks from which feed can be supplied. The use of these tanks is the most practical alternative for handling the processed supernate. Three options exist for using tanks W-29 and W-30 for storage of the processed liquid from the CRD. The first option is to return the liquid back to the same tank from which the feed is supplied. In this case, the cesium concentration within the tank would be reduced approximately exponentially. The primary advantage of this option is that the storage capacity in the second tank is not taken up while the demonstration is being conducted. While this is not the most desirable method of operation, it is a satisfactory method for demonstration of cesium removal and will be beneficial if the supernate is processed in a solidification campaign. The second option is to feed from one tank and return the processed supernate to the second tank. The third option would be to conduct the CRD in conjunction with a solidification campaign. With this alternative, the waste from either W-29 or W-30 would be processed through the CRD system and the processed supernate would be pumped directly into a container for 
solidification. This option would prevent having to pump the treated supernate back into the MVST where the cesium remaining in the sludge could possibly diffuse into the supernate. Use of the two MVSTs and the processing alternative to be used will have to be determined from discussions with WMRAD personnel.

\subsection{LOADED ION-EXCHANGE RESINS}

Ongoing studies by Bibler indicate that gas will be generated when SRR is exposed to high levels of radiation during storage. ${ }^{8}$ It is expected that little or no gas generation will occur if inorganic materials such as $\mathrm{KCoCF}$ and CST are used. An acceptable practice in the nuclear reactor industry is the installation of a filtered vent in the storage container to prevent pressure buildup. Methods of drying as well as detection and prevention of gas buildup during storage will be incorporated in the design of the CRD system. Heat generation from radioactive decay of the ${ }^{137} \mathrm{Cs}(4.835 \mathrm{~W} / 1000 \mathrm{Ci})$ in the ion-exchange material is not expected to be a problem during operation or storage. ${ }^{45}$

Prior to removing the ion-exchange columns from the CRD system, the columns will be rinsed with $0.16 \mathrm{M}$ sodium hydroxide and water to prevent precipitation of aluminum and to remove residual nitrates, respectively. The resin in the columns will also be dried with air and/or vacuum to remove free water prior to removing the columns. On-site interim storage of loaded ion-exchange columns will likely 
be required prior to permanent off-site disposal because at the present time there is no approved off-site disposal facility. Interim storage will also be necessary to permit accumulation of enough material to fill a shipping cask.

Two options have been considered for interim storage at ORNL for the loaded ion-exchange media from the process. This includes (1) storage in aboveground vaults and/or in retrievable underground storage wells or (2) storage in an existing hot cell facility. Some types of organic resins loaded with radioactive material are currently being stored on an interim basis in aboveground vaults and in retrievable underground storage wells at ORNL. ${ }^{46}$ While the ion-exchange columns from the CRD can be made to meet the technical requirements for this type of storage, this method is currently being permitted only on an emergency basis and may not be allowed for the CRD resin. The second option is for interim storage in an existing hot cell facility such as Building 3517. This building is currently used for storage of cesium and other radioisotopes. Use of Building 3517 would require approval by DOE; however, it is expected that approval would be granted..$^{45}$ Necessary modifications to the building for interim storage would include the addition of storage racks and possible modifications to entry ports. ${ }^{45}$

Two potential options have also been identified for permanent disposal of the spent resin. These options are (1) disposal at the Nevada Test Site or (2) vitrification and storage at the SRS. Discussions with personnel from ORNL WMRAD 
indicate that the loaded resin could potentially be sent to the Nevada Test Site. ${ }^{47}$ The waste acceptance criteria for the Nevada Test Site will be considered in the design of the CRD system. ${ }^{48}$

The second option for disposal of the resin is through a cooperative effort with the SRS. SRS personnel have expressed an interest in using the radioactive resin from the $\mathrm{CRD}$ to demonstrate vitrification of loaded resins at facilities located at Savannah River. ${ }^{49}$ Recent discussions have indicated that SRS personnel would like to process the resin but that it might be necessary to ship the vitrified resin back to ORNL for storage. It is expected that the volume of vitrified waste shipped from SRS would be much less than the original volume of loaded resin treated. Also, the vitrified resin would be a much better waste form for storage. It is possible that vitrified waste could be transported to the Nevada Test Site for final disposal.

A transport cask has been identified at ORNL that is suitable for use in transporting loaded resin from the CRD site to an interim storage site at ORNL. The carrier has a cavity that is $14-13 / 16$ in. in diameter by $41-5 / 16$ in. long and weighs $9640 \mathrm{lb}^{50}$ It has $0.75 \mathrm{in}$. of steel and 2.84 in. of lead shielding. ${ }^{50}$ Vendors have also been identified who provide licensed shipping casks for the transport of loaded ion-exchange material over the highways. ${ }^{51,52}$ However, specific details for storage and shipment of ion-exchange material loaded with cesium have not been 
worked out. The CRD system will be designed to incorporate features needed for the transportation, interim storage, and permanent storage of the resin.

\subsection{CONTAMINATED FILTERS}

The supernate that will be used for feed in the CRD will be withdrawn well above the sludge layer in the tanks after the sludge has been allowed to settle for an extended period. As a result, the supernate is not expected to have any appreciable suspended solids. In bench-scale column tests conducted to date, it has been normal practice to filter the MVST supernate prior to performing tests in ion-exchange columns as a precaution against the buildup of solids that might cause plugging or reduce the efficiency of the column. In general, very little material has been collected by the filters; however, since a filter should be included in the system ahead of the ion-exchange columns, since there are no specific data to show that filtration can be eliminated. Filtration will also be necessary if $\mathrm{pH}$ adjustment of the feed is required. Provisions should be made to dry the filter to remove all free water. This would allow the material to be stored on site or possibly transferred off site for final disposal. If a filter is placed in the CRD system, it should be designed to be removed by the same carrier used to transport the $\mathrm{CRD}$ resin columns. 


\subsection{ACID ELUENT FROM REGENERATION OF LOADED RESINS}

If the ion-exchange resin were to be eluted, the majority of the contamination would be transferred to the acid eluent. The residual contamination on the regenerated resin would dictate the disposal options for that resin. The alternatives for handling the acid eluent from the regeneration of loaded ionexchange columns include (1) transferring the acid eluent back into the MVSTs or (2) pumping the acid eluent through a column containing a different ion-exchange material to remove the cesium. The first option would eliminate the advantage of removing the cesium from the MVST waste, which will be necessary for future solidification of this waste. The second option demonstrates the concept of resin regeneration, but there is still the loaded resin which would have to be dealt with by interim and/or permanent disposal. The second option would also require additional development work on the ion exchanger to be used to treat the eluent. For example, AMP may be applicable but it is not available in an engineered form. KCoCF could possibly be used, but the same limitations as those discussed in Sect. 2.5 of this report would apply.

\section{RELATIVE COST COMPARISON}

A limited number of cesium removal batch tests have been run with SRR, KCoCF, and CST using actual MVST supernate from W-25. In these tests, the distribution 
coefficient ranged from 26,000 to $46,200 \mathrm{~mL} / \mathrm{g}$ for $\mathrm{KCoCF}$, from 138 to $764 \mathrm{~mL} / \mathrm{g}$ for SRR, and from 451 to $958 \mathrm{~mL} / \mathrm{g}$ for CST. The cesium loading that can be achieved on any of the ion-exchange materials is dependent on the cesium concentration in the solution. At a cesium concentration of $1.43 \times 10^{-3} \mathrm{meq} / \mathrm{L}$, which is the concentration in W-25, cesium loadings for KCoCF, CST, and SRR were approximately 50,8 , and $4 \mathrm{meq} / \mathrm{kg}$, respectively. These loadings were achieved after long contact times between the ion-exchange materials and the supernate. While it may be theoretically possible to achieve these loadings in columns, it is not practical because breakthrough occurs before the column is fully loaded. Therefore, for comparison purposes, the loadings obtained from these batch tests can be used to calculate the minimum quantity of ion-exchange material required. The total quantity of cesium contained in $25,000 \mathrm{gal}(\sim 95,000 \mathrm{~L})$ of W25 supernate is $133 \mathrm{meq}$. Based on the above loadings, the total quantity of cesium in W-25 could be removed with $2.7 \mathrm{~kg} \mathrm{KCoCF}, 16.6 \mathrm{~kg} \mathrm{CST}$, or $33.3 \mathrm{~kg}$ SRR.

More realistic estimates on the quantities of ion-exchange materials required for the cesium removal demonstration can be obtained from column tests. In column tests with SRR using simulated supernate (not necessarily with the same cesium concentration), initial cesium breakthrough has typically occurred after from 40 to 100 bed volumes of liquid has gone through the column. In tests with MVST simulant, Campbell and $\mathrm{Lee}^{2}$ reported that $50 \%$ breakthrough occurred in the 
range of 350 bed volumes. Assuming the $\mathrm{CRD}$ system can be operated to $50 \%$ breakthrough, $\sim 350$ bed volumes could be treated prior to resin changeout. Based on these values and the use of a 15-gal (57-L) ion-exchange column, approximately 5 bed volumes of SRR would be required to treat $25,000 \mathrm{gal}$ of MVST supernate. Assuming an ion-exchange density of $1.6 \mathrm{~g} / \mathrm{cm}^{3}, \sim 400 \mathrm{~kg}$ or resin would be required (assuming no regeneration).

Column test data with MVST supernate are not available for KCoCF or CST. However, an estimate of the relative quantities needed can be made from distribution coefficients data. Based on the relative distribution coefficients, the quantity of CST powder required is approximately half that for the SRR granules. Since an engineered formed of CST will require the use of inert binders, which will lower the loading capacity of the CST, it will be assumed that the loading capacities of SRR and CST are essentially equal. Therefore, $\sim 400 \mathrm{~kg}$ of CST would also be required to process $\sim 25,000 \mathrm{gal}$ of MVST supernate (based on 350 bed volumes processed per column). Based on the distribution coefficients, the quantity of $\mathrm{KCOCF}$ is expected to be on the order of 100 times less than that required for CST or SRR, which would mean that $\sim 8.8 \mathrm{~kg}$ of $\mathrm{KCoCF}$ would be required to treat 25,000 gal of W-25 supernate. Using the above assumptions and resin costs provided by Rodney Hunt, ${ }^{7}$ a rough comparison of the relative costs of treating 25,000 gal of MVST supernate is presented in Table 1. 
Table 1. Estimate of the relative costs of treating 25,000 gallons of supernate with potassium cobalt hexacyanoferrate (KCoCF), Savannah River resin (SRR), and crystalline silicotitanates (CST), based on the estimated resin costs only

\begin{tabular}{lccccc}
\hline $\begin{array}{c}\text { Resin } \\
\text { type }\end{array}$ & $\begin{array}{c}\text { Unit cost } \\
(\$ / \mathrm{kg})\end{array}$ & $\begin{array}{c}\text { Minimum } \\
\text { quantity } \\
(\mathrm{kg})\end{array}$ & $\begin{array}{c}\text { Estimated } \\
\text { quantity } \\
(\mathrm{kg})\end{array}$ & $\begin{array}{c}\text { Minimum } \\
\text { cost } \\
(\$)\end{array}$ & $\begin{array}{c}\text { Estimated } \\
\text { cost } \\
(\$)\end{array}$ \\
\hline KCoCF & 5,000 & 2.7 & 8.8 & 13,500 & 44,000 \\
SRR & 35 & 33.3 & 450 & 1,200 & 16,000 \\
CST & 275 & 16.6 & 450 & 4,600 & 124,000 \\
\hline
\end{tabular}

As can be seen, there would only be a difference of $\sim \$ 28,000$ in the estimated cost between the KCoCF and SRR required to treat 25,000 gal of supernate. However, the relative difference between the necessary SRR and CST would be $\sim \$ 108,000$. It should be noted that the above relative costs are rough estimates based on the data available at the time this report was written. Laboratory column tests using actual MVST supernate is planned for FY 1995. Data from these tests will provide much better estimates of the cesium loadings that can be expected in the CRD system. Transportation and storage requirements could also limit the amount of cesium that could be loaded onto a single column. These factors could significantly impact the cost of the resin necessary for the CRD. For example, if only 100 bed volumes of supernate could be processed before resin changeout, the estimated cost for the SRR and the CST would be $\sim \$ 55,000$ and $\sim \$ 25,000$, respectively. 


\section{RECOMMENDATIONS}

A comparison of the advantages and disadvantage of the three materials, SRR, $\mathrm{CST}$, and $\mathrm{KCoCF}$, considered to be primary candidates for use in the cesium removal demonstration system is presented in Table 2. Although laboratory studies have indicated that all three materials have sufficient capacity for demonstrating the removal of cesium from up to 25,000 gal of MVST supernate in a reasonable period, the loading capacity is approximately an order of magnitude higher for KCoCF than it is for either SRR or CST. The loading capacity of $\mathrm{KCoCF}$ is large enough that it could be considered for use in a slurry process to remove cesium. However, a slurry system would add operational complexity to the demonstration due to necessary filtration and slurry handling capabilities and is not recommended for use in CRD. The major disadvantage associated with the use of $\mathrm{KCoCF}$ is the prior DOE-wide concerns regarding the potential for a hazardous exothermic reaction resulting from reaction of $\mathrm{KCoCF}$ and nitrates in wastes stored at Hanford. Although the process could be designed to wash nitrates from the resin before storage, thus eliminating the problem, discussions indicate that Hanford and the Savannah River would probably not consider the use of KCoCF at their facilities. ${ }^{53}$ Other discussions with SRS personnel have indicated that extensive development work regarding the safety of KCoCF and nitrates would be necessary prior to vitrification demonstrations with loaded

KCoCF at their hot cell facilities. ${ }^{53}$ As a result, the use of KCoCF could eliminate 
Table 2. Summary of the advantages and disadvantages of Savannah

River resin (SRR), crystalline silicotitanates (CST), and potassium cobalt hexacyanoferrate (KCoCF) for use in the cesium

removal demonstration system

\begin{tabular}{|c|c|c|c|}
\hline Advantage/Disadvantage & SRR & CST & $\mathrm{KCOCF}$ \\
\hline Distribution coefficient $\mathrm{mL} / \mathrm{g}$ & $138-764$ & $451-958$ & $26,000-46,000$ \\
\hline $\begin{array}{l}\text { Cesium loading from equilibrium data, } \\
\mathrm{meq} / \mathrm{kg}\end{array}$ & 4 & 8 & 50 \\
\hline $\begin{array}{l}\text { Estimated resin cost for treating } \\
25,000 \text { gal of MVST supernate }\end{array}$ & $\$ 16,000$ & $\$ 124,000$ & $\$ 44,000$ \\
\hline $\begin{array}{l}\text { Cesium loading large enough to treat } \\
25,000 \text { gal of MVST in a time period } \\
\text { reasonable for the CRD }\end{array}$ & $\mathbf{Y}$ & $\mathrm{Y}$ & $\mathrm{Y}$ \\
\hline $\begin{array}{l}\text { Distribution coefficient decreases with } \\
\text { increasing potassium concentration }\end{array}$ & Y & $\mathbf{N}$ & $\mathbf{N}$ \\
\hline $\begin{array}{l}\text { Batch tests conducted with MVST } \\
\text { supernate }\end{array}$ & $\mathrm{Y}$ & $\mathrm{Y}$ & $\mathbf{Y}$ \\
\hline $\begin{array}{l}\text { Column tests conducted with MVST } \\
\text { supernate }\end{array}$ & $\mathrm{N}$ & $\mathrm{N}$ & $\mathbf{N}$ \\
\hline $\begin{array}{l}\text { Column tests conducted with surrogate } \\
\text { waste }\end{array}$ & $\mathbf{Y}$ & $\mathbf{N}$ & $\mathbf{N}$ \\
\hline Regeneration methods developed & $\mathrm{Y}$ & $\mathrm{N}$ & $\mathbf{N}$ \\
\hline Engineered form presently available & $\mathbf{Y}$ & $\mathbf{N}$ & $\mathbf{Y}$ \\
\hline $\begin{array}{l}\text { Considered for use as an alternative at all } \\
\text { three DOE sites (ORNL, SRS, Hanford) }\end{array}$ & $\mathbf{Y}$ & $\mathbf{N}$ & $\mathbf{N}$ \\
\hline $\begin{array}{l}\text { Gas generated during storage due to } \\
\text { exposure to radiation }\end{array}$ & $\mathrm{Y}$ & $\mathrm{N}$ & N \\
\hline $\begin{array}{l}\text { Can be vitrified at SRS without extensive } \\
\text { development studies }\end{array}$ & $\mathbf{Y}$ & $\mathbf{Y}$ & $\mathbf{N}$ \\
\hline $\begin{array}{l}\text { Concern expressed regarding possible } \\
\text { explosive reaction with nitrates }\end{array}$ & $\mathrm{N}$ & $\mathrm{N}$ & $\mathbf{Y}$ \\
\hline $\begin{array}{l}\text { Adjustment of } \mathrm{pH} \text { required for treatment } \\
\text { of MVST supernate }\end{array}$ & $\mathrm{N}$ & $\mathrm{N}$ & $\mathbf{Y}$ \\
\hline
\end{tabular}


the option of vitrifying the loaded resins from the CRD at the SRS. Since the CRD should generate information that could potentially be useful at all three DOE sites, it is recommended that $\mathrm{KCoCF}$ not be used in the cesium removal demonstration.

Batch tests using SRR and CST have resulted in distribution coefficients and cesium loadings on the same order of magnitude, and it is expected that similar quantities of resin would be required for either material. The primary disadvantages of the SRR are that high potassium concentrations could drive down the cesium loading for this resin and that gas is generated during the storage of the resin. The primary disadvantages of the CST are that an engineered form of the material is not available at this time and it is expected that if an engineered form becomes available in time for use in the demonstration, it will be relatively expensive. Because an engineered form of CST has not been available, there has been limited testing on that material. Much more data exists regarding the use of SRR on sodium nitrate-based wastes. Another advantage for use of SRR is that all three DOE sites, ORNL, SRS, and Hanford, have expressed an interest in SRR and have included it in their plans as a possible alternative. As a result, it is recommended that design of the CRD system move forward based on the test results to date obtained for SRR. The problem of gas buildup during storage can be overcome by venting the stored columns through HEPA filters. Column tests to be conducted through task OR-132008-E (Hot Demonstration of Proposed 
Commercial Nuclide Removal Technology) using SRR with actual MVST supernates during FY 1995 will provide design data for the CRD system.

These design data will include cesium loading capacities expected during the actual processing of the MVST LLLW. Column tests are also expected to be conducted with CST when an engineered form becomes available. It is expected that processing requirements for SRR and CST (i.e., flow rates, column design, $\mathrm{pH}$ requirements, etc.) will be similar enough so that CST could also be used in the CRD system if (1) an engineered form becomes available, and (2) the Hot Demonstration of Proposed Commercial Nuclide Removal Technology tests (OR132008-E) show that use of the CST in the demonstration is warranted. However, until additional data are available, design of the CRD system should proceed based on the use of SRR.

It should be noted that design data for the CRD system are to be provided by column studies to be conducted through task OR-132008-E (Hot Demonstration of Proposed Commercial Nuclide Removal Technology) in early FY 1995. Design of the CRD system can proceed based on the current information available with SRR. However, use of these data results in uncertainties regarding the cesium loading capacities which can be expected from the actual waste. If design of the CRD system proceeds without the results from these bench-scale column tests, modifications to that design might be necessary when bench-scale data become available. 
It can also be seen from Table 2 that regeneration methods have been developed only for SRR. Demonstration of the elution of cesium from SRR would be important to determine operating parameters such as resin degradation during regeneration; however, given that operation of the unit has to be initiated during FY 1996 and that modifications of safety documentation might be much more difficult if regeneration is included, it is believed that regeneration is beyond the scope of this project. Therefore, it is recommended that design of the system proceed based on the operation of a once-through system without the capability for regeneration. It is also recommended that the system be designed so that a modular regeneration unit can be added to the CRD system in case DOE wants to fund work on regeneration at a later time.

Table 3 provides a summary of CRD facility requirements that have been met by each of the four facilities. As can be seen, only Building 7877 (the Liquid LowLevel Waste Solidification Facility) meets, or can be modified within the time frame and budget allotted, all requirements for placement of the demonstration system. Therefore, use of Building 7877 is recommended for operation of the CRD system. It should be noted that this building is currently being used for solidification campaigns and is scheduled for use with the OTED during FY 1995. Use of Building 7877 for the CRD demonstration will have to be scheduled with ORNL WMRAD to prevent conflicts with their plans. 
Table 3. Summary of facility requirements necessary for operation of the cesium removal demonstration system

\begin{tabular}{lcccc}
\hline \multicolumn{1}{c}{ Facility requirements } & 7877 & 7860 & 3517 & 7930 \\
\hline $\begin{array}{l}\text { Contains a HEPA ventilation system } \\
\begin{array}{l}\text { Has pipelines from MVSTs (not on } \\
\text { bottom of tank) }\end{array}\end{array}$ Y & $\mathrm{Y}$ & $\mathrm{Y}$ & $\mathrm{Y}$ \\
$\begin{array}{l}\text { Has pipelines to MVST or to LLLW } \\
\text { evaporator }\end{array}$ & $\mathrm{Y}$ & $\mathrm{Y}$ & $\mathrm{Y}$ & $\mathrm{Y}$ \\
$\begin{array}{l}\text { Requires major modification to safety } \\
\text { documentation }\end{array}$ & $\mathrm{N}$ & $\mathrm{Y}$ & $\mathrm{N}$ & $\mathrm{Y}$ \\
$\begin{array}{l}\text { Requires major building or piping } \\
\text { modifications }\end{array}$ & $\mathrm{N}$ & $\mathrm{Y}$ & $\mathrm{Y}$ & $\mathrm{Y}$ \\
$\begin{array}{l}\text { Modifications could be made within } \\
\text { time frame and budget allotted for the }\end{array}$ & $\mathrm{Y}$ & $\mathrm{N}$ & $\mathrm{N}$ & $\mathrm{N}$ \\
CRD & & & & \\
\hline
\end{tabular}

Operation of the CRD system on a once-through basis with the processed supernate being returned to the MVSTs will require that loaded resin be stored on site or transferred to a permanent storage facility. The material would have to stored at an interim storage facility at ORNL prior to being shipped to the permanent storage facility. It is recommended that Building 3517 be used for interim storage of the loaded resin until it can be transported to a permanent storage facility. Minor modifications of Building 3517 might be necessary. It is also recommended that the joint effort between ORNL and SRS on the demonstration of the ability to vitrify the loaded resin from the CRD be pursued. Even if the vitrified resin is returned to ORNL, the volume will be substantially reduced and the waste form will be improved. 
Discussions with WMRAD personnel have indicated that it might be possible to permanently dispose of the loaded resins (or the vitrified resins) at the Nevada Test Site. When designing the CRD system, the waste acceptance criteria for the Nevada Test Site as well as the requirements for on-site and over-the-road transportation should be kept in mind. Personnel within the Chemical Technology Division who will conduct the demonstration and WMRAD who will ultimately be responsible for final disposal of the waste, should work closely together to ensure the best alternatives are chosen for interim and permanent disposal. Personnel at SRS who developed the resin and who have done extensive bench-scale studies with the resin should also be contacted for information regarding the stability of the loaded resin during long-term storage.

A simplified schematic diagram of the conceptual cesium removal demonstration system is presented in Fig. 6. Based on the information to date, the following recommendations are made.

1. The system should contain two ion-exchange columns which should be piped to operate in parallel or in series. Piping should also allow either of the columns to operate while the other column is off line. This configuration would allow operational flexibility and would also be advantageous if resin regeneration were tested at a later date. 


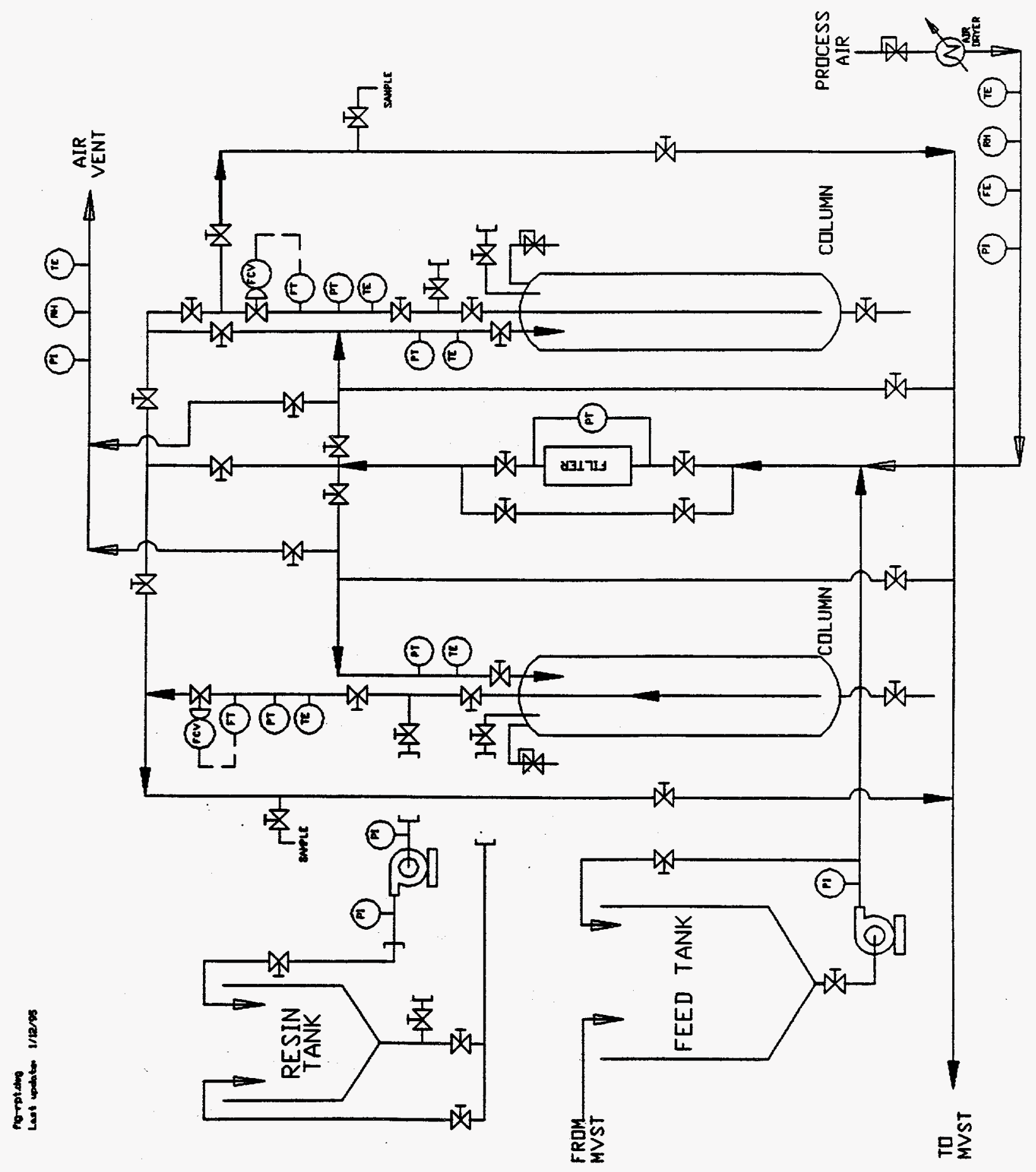

Fig. 6. A schematic diagram of the conceptual cesium removal demonstration system. 
2. The columns should be sized to fit the carrier identified for on-site transportation at ORNL, which has a cavity that is $14-13 / 16$ in. in diameter by 41-5/16 in. long. This would allow a column with an approximate diameter of 12 in. and a resin bed height of 30 in. to be used. This size column will allow processing at a rate of approximately $1 \mathrm{gpm}$ with axial flows in between those used in small-scale column tests and the designed axial flow of the SRS SKID unit. Depending on whether the CRD system operates $8 \mathrm{~W} /$ day or $24 \mathrm{~h} /$ day, 15 to 22 weeks would be required to process up to 25,000 gal of MVST supernate at this flow rate (assuming 1 week is required to change out the resin bed each time it becomes loaded with cesium).

3. The columns should be designed to allow the resins to be sluiced into or out of the columns. If sluicing is used to remove the resin from the column, a shielded high-integrity container (HIC) will have to be provided for receiving the resin. A sluicing system should be included in the CRD system. The sluicing system should be demonstrated by the vendor with the material to be used in the CRD system.

4. The columns should be designed so that they can be used as a storage containers. Discussions with SRS personnel have indicated a preference for transporting the resins to SRS still loaded in the ion-exchange columns if the resin is to be vitrified in their hot cell facility. Since the system will be designed 
so that the material can be sluiced out of the columns into a separate container, this will not preclude the use of sluicing the material into a high-integrity container for transport or storage if desired.

5. A filter should be included to remove solids from the supernate before it is processed through the ion-exchange column(s). Information on filtration requirements should come from bench-scale tests to be conducted through OR132008-E (Hot Demonstration of Proposed Commercial Nuclide Removal Technology) in FY 1995.

6. Provisions to remove free water from the filters and the columns should be incorporated into the design to account for shipping and storage requirements.

7. The CRD system should be skid mounted and designed so that it can be transported to different facilities. Primary containment would be provided by the ion-exchange columns. These columns should be vented to the feed tank or the MVST return line. The equipment should be located in a pan that could be drained back into the MVSTs if necessary. The system should also be encased in a stainless steel enclosure to provide secondary containment. This enclosure should be vented through the Building 7877 HEPA filtration system. 


\section{REFERENCES}

1. E. L. Youngblood, personal communication with J. L. Collins.

2. D. O. Campbell and D. D. Lee, Treatment Options and Flowsheets for ORNL Low-Level Liquid Waste Supernate, ORNL/TM-11800, December 1991.

3. T. E. Kent, J. F. Villiers-Fisher, and F. E. Harrington, Selection of an Interim Upgrade Strategy for the Process Waste Treatment Plont at ORNL, ORNL/TM-11384, January 1991.

4. Personal communication from J. P. Bibler to P. A. Haas, July 20, 1994.

5. L. A. Bray, C. D. Carlson, K. J. Carson, J. R. DesChane, R. J. Elovich, D. E. Kurath, Initial Evaluation of Two Organic Resins and their Ion Exchange Column Performance for the Recovery of Cesium from Hanford Alkaline Wastes, TWRSPPP-93-055, August 1993.

6. Cesium Separations Technology Workshop, August 4-5, 1994, Pacific Northwest Laboratory, Richland, Washington.

7. Personal communications with R. D. Hunt, December 5, 1994.

8. J. P. Bibler, Year-end Report on Work Performed for Technical Task Plan \#SRI-02-20-01, Cs Extraction Studies (U), February 1, 1994.

9. J. L. Collins, B. Z. Egan, K. K. Anderson, C. W. Chase, J. T. Bell, and G. E. Jernigan, Evaluation of Selected Ion Exchangers for the Removal of Cesium and Strontium from MVST W-25 Supernate, Interim progress to DOE office of Technology USTID.

10. W. D. Arnold, D. T. Bostic, M. W. Burgess, P. A. Taylor, J. J. Perona, T. E. Kent, Laboratory Development of Methods for Centralized Treatment of Liquid Low-Level Waste at Oak Ridge National Laboratory, ORNL/TM12786, October 1994.

11. D. E. Kurath, L. A. Bray, K. P. Brooks, G. N. Brown, S. A. Bryan, C. D. Carlson, K. J. Carson, J. R. DesChane, R. J. Elovich, and A. Y. Kim, Experimental Data and Analysis to Support the Design of an Ion Exchange Process for the Treatment of Hanford Tank Waste Supernatant Liquids, TWRSPP-94-010, January 1994. 
12. D. O. Campbell, D. D. Lee, and T. A. Dillow, Low-Level Liquid Waste Decontamination by Ion Exchange, ORNL/TM-11891, December 1991.

13. FY-1995 Technical Task Plan for Hot Demonstration of Proposed Commercial Nuclide Removal Technology, TTP No. OR132008.

14. R. R. Brunson, D. F. Williams, W. D. Bond, D. E. Benker, F. R. Chattin, and E. D. Collins, Removal of Cesium from Aluminum Decladding Wastes Generated in Irradiated Target Processing Using a Fixed-Bed Column of Resorcinol-Formaldehyde Resin, ORNL/TM-12708, July 1994.

15. J. P. Bibler and M. L. Myers, Ion Exchange at TNX Using the SKID Unit (U), WSRC-TR-93-564 Rev. 0, October 21, 1993.

16. J. F. Walker, personal communication with Norman Brown, December 19, 1995.

17. P. A. Haas, "A Review of Information on Ferrocyanide Solids for Removal of Cesium from Solutions," Separation Science and Technology 29 (17\&18), 2479-2506 (1993).

18. B. C. Simpson, H. Babad, and R. J. Cash, "Recent Results from Characterization of Ferrocyanide Wastes at the Hanford Site," WHC-SA1701-FP, February 1993, presented at Waste Management ' 93 Symposium, Tucson, Arizona, February 28 to March 4, 1994.

19. Conceptual Design Report for the Waste Handling and Packaging Plant, Technical Information Document, Volume 1, X-OE-506, October 1990.

20. E. H. Tusa, A. Paavola, R. Harjula and J. Lehto, Industrial Scale Removal of Cesium with Hexacyanoferrate Exchanger - Process Realization and Test Run, presented at Waste Management ' 93 Symposium, in Tucson, Arizona, February 28 to March 4, 1994.

21. Letter from IVO International, LTD, to T. E. Kent, March 19, 1993.

22. Letter from The Valley Group, Finnish Nuclear Waste Technologies, to J. F. Walker, November 28, 1994.

23. J. F. Walker personal communication with J. L. Collins.

24. M. B. Sears, J. L. Botts, R. N.Ceo, J. J. Ferrada, W. H. Griest. J. M. Keller, and R. L. Schnely, Sampling and Analysis of Radioactive Liquid Wastes and 
Sludges in the Melton Valley and Evaporator Facility Storage Tanks at ORNL, ORNL/TM-11652, September 1990.

25. J. Lehto and L. Szirtes, "Effects of Gamma Irradiation on Cobalt Hexacyanoferrate(II) Ion Exchangers," Radiat. PHY.Chem., 1993.

26. J. Lehto, S. Haukka, P. Koskenen, and M. Blomberg, "Thermal Decomposition of Potassium Cobalt Hexacyanoferrate," Thermochimica Acta., 160, 343-347 (1990).

27. W. Faubel and A. Ali Sameh, "Separation of Cesium from Acid ILW-Purex Solutions by Sorption on Inorganic Ion Exchangers," Radiochimica Acta 40, 49-56 (1986).

28. E. L. Youngblood, personal communication with G. L. Goken, October 28, 1994.

29. E. L. Youngblood, personal communication with J. H. Platfoot, August 23, 1994.

30. Safety Study, Liquid Low-Level Waste Solidification Facility Building 7877, ORNL/ENG/SS2 Rev.

31. T. F. Scanlan and C. B. Scott, ORNL Maintenance and Surveillance Plan for the New Hydrofracture Facility, 1988.

32. Final Safety Analysis Report for the New Hydrofracture Facility at Oak Ridge National Laboratory, ORNL/ENG/TNF-81/2, May 1982.

33. J. F. Walker, personal communication with $\mathrm{K}$. W. Haff, Manager, Building 3517, December 9, 1994.

34. Final Safety Analysis Report For Fission Product Development Laboratory, Building 3517. (Report No. and date)

35. C. P. McGinnis, D. Foster, Jr., P. A. Haas, K. W. Haff, D. W. Holladay, D. W. Malkemus, and D. W.Ramey, Cost Estimate for Pilot Plant Operations of Sludge and Liquid Processes, Internal ORNL Document, October 1992.

36. Letter from G. D. West to S. M. Robinson, September 19, 1994.

37. J. F. Walker, personal communication with V. L. Fowler, January 1995. 
38. J. F. Walker, personal communication with T. E. Kent, June 29, 1994.

39. J. F. Walker, personal communication with Lane Bray, October 28, 1994.

40. Letter from J. P. Bibler to P. A. Haas, July 20, 1994.

41. J. F. Walker, personal communication with Mark Neville, AEA Technology Environmental Electrochemistry Manager, January, 19, 1995.

42. J. F. Walker, personal communication with J. L. Collins, November 28, 1994.

43. J. F. Walker, personal communication with J. P. Bibler, October 19, 1994.

44. Letter from B. L. Broadhead to E. L. Youngblood, "Dose Rate Calculations for Cs Ion Exchange Column," November 21, 1994.

45. J. F. Walker, personal communication with $\mathrm{K}$. W. Haff, Manager, Building 3517, December 9, 1994.

46. J. F. Walker, personal communication with B. C. McClelland, October 3, 1994.

47. J. F. Walker, personal communication with John Trabalka and D. M. Ferren, October 24, 1994.

48. Nevada Test Site Defense Waste Acceptance Criteria, Certification, and Transfer Requirements, NVO- 325(Rev. 1), June 1992.

49. J. F. Walker, personal comunication with John Plodinec and Amy Applewhite-Ramsey, January 18, 1995.

50. J. F. Walker, personal communication with Charles Devore.

51. E. L. Youngblood, personal communication with Dave McCoy, Scientific Ecology Group, Inc., November 1, 1994.

52. J. F. Walker, personal communication with David L. Presley, Chem-Nuclear Systems., Inc., December 12, 1994.

53. J. F. Walker, personal communication with Bill Richmond, August 9, 1994. 


\section{INTERNAL DISTRIBUTION}

1. P. A. Arakawa

2. W. D. Bond

3. D. A. Bostick

4. E. D. Collins

5. J. L. Collins

6. D. J. Davidson

7. B. Z. Egan

8. R. D. Hunt

9. T. E. Kent

10. D. D. Lee

11. J. J. Maddox

12. C. P. McGinnis

13. D. R. McTaggart

14. D. J. Peterson
15. W. R. Reed

16. S. A. Richardson

17. S. M. Robinson

18. C. B. Scott

19. P. A. Taylor

20. W. T. Thompson

21-30. J. F. Walker, Jr.

31. Central Research Library

32. Document Reference Section

33-34. Laboratory Records

35. Laboratory Records-RC

36. ORNL Patent Section

\section{EXTERNAL DISTRIBUTION}

37. Office of Assistant Manager, Energy Research and Development, DOEOR, P.O. Box 2001, Oak Ridge, TN 37831.

38-39. Office of Scientific and Technical Information, DOE, P.O. Box 62, Oak Ridge, TN 37831 